\title{
Long-range-transported Canadian smoke plumes in the lower stratosphere over northern France
}

\author{
Qiaoyun Hu${ }^{1}$, Philippe Goloub ${ }^{1}$, Igor Veselovskii ${ }^{2}$, Juan-Antonio Bravo-Aranda ${ }^{3}$, Ioana Elisabeta Popovici ${ }^{1,4}$, \\ Thierry Podvin $^{1}$, Martial Haeffelin ${ }^{3}$, Anton Lopatin ${ }^{5}$, Oleg Dubovik ${ }^{1}$, Christophe Pietras ${ }^{3}$, Xin Huang ${ }^{5}$, \\ Benjamin Torres ${ }^{1}$, and Cheng Chen ${ }^{1}$ \\ ${ }^{1}$ Univ. Lille, CNRS, UMR8518 - LOA - Laboratoire d'Optique Atmosphérique, 59000 Lille, France \\ ${ }^{2}$ Physics Instrumentation Center of GPI, Troitsk, Moscow, 142190, Russia \\ ${ }^{3}$ Institut Pierre Simon Laplace, École Polytechnique, CNRS, Université Paris-Saclay, 91128 Palaiseau, France \\ ${ }^{4}$ CIMEL Electronique, 75011 Paris, France \\ ${ }^{5}$ GRASP-SAS, Remote sensing developments, 59650 Villeneuve-d'Ascq, France
}

Correspondence: Qiaoyun Hu (qiaoyun.hu@univ-lille.fr)

Received: 29 June 2018 - Discussion started: 9 July 2018

Revised: 14 December 2018 - Accepted: 19 December 2018 - Published: 30 January 2019

\begin{abstract}
Long-range-transported Canadian smoke layers in the stratosphere over northern France were detected by three lidar systems in August 2017. The peaked optical depth of the stratospheric smoke layer exceeds 0.20 at $532 \mathrm{~nm}$, which is comparable with the simultaneous tropospheric aerosol optical depth. The measurements of satellite sensors revealed that the observed stratospheric smoke plumes were transported from Canadian wildfires after being lofted by strong pyro-cumulonimbus. Case studies at two observation sites, Lille (lat 50.612, long 3.142, $60 \mathrm{~m}$ a.s.1.) and Palaiseau (lat 48.712, long 2.215, $156 \mathrm{~m}$ a.s.1.), are presented in detail. Smoke particle depolarization ratios are measured at three wavelengths: over 0.20 at $355 \mathrm{~nm}, 0.18-0.19$ at $532 \mathrm{~nm}$, and $0.04-0.05$ at $1064 \mathrm{~nm}$. The high depolarization ratios and their spectral dependence are possibly caused by the irregular-shaped aged smoke particles and/or the mixing with dust particles. Similar results are found by several European lidar stations and an explanation that can fully resolve this question has not yet been found. Aerosol inversion based on lidar $2 \alpha+3 \beta$ data derived a smoke effective radius of about $0.33 \mu \mathrm{m}$ for both cases. The retrieved single-scattering albedo is in the range of 0.8 to 0.9 , indicating that the smoke plumes are absorbing. The absorption can cause perturbations to the temperature vertical profile, as observed by ground-based radiosonde, and it is also related to the ascent of the smoke plumes when exposed in sunlight. A direct radiative forc-
\end{abstract}

ing (DRF) calculation is performed using the obtained optical and microphysical properties. The calculation revealed that the smoke plumes in the stratosphere can significantly reduce the radiation arriving at the surface, and the heating rate of the plumes is about $3.5 \mathrm{~K} \mathrm{day}^{-1}$. The study provides a valuable characterization for aged smoke in the stratosphere, but efforts are still needed in reducing and quantifying the errors in the retrieved microphysical properties as well as radiative forcing estimates.

\section{Introduction}

Stratospheric aerosols play an important role in the global radiative budget and chemistry-climate coupling (Deshler, 2008; Kremser et al., 2016; Shepherd, 2007). Volcanic eruption is a significant contributor of stratospheric aerosols because the explosive force could be sufficient enough to penetrate the tropopause, which is regarded as a barrier to the convection between the troposphere and stratosphere. In addition to volcanic eruption, biomass burning has been reported to be one important constituent of the increasing stratospheric aerosols (Hofmann et al., 2009; Khaykin et al., 2017; Zuev et al., 2017). The pyro-cumulonimbus clouds generated in intense fire activities have the potential to elevate fire emissions from the planetary boundary layer to the stratosphere 
(Luderer et al., 2006; Trentmann et al., 2006). Stratospheric smoke plumes have been reported in many previous studies (Fromm et al., 2000, 2005; Fromm and Servranckx, 2003; Sugimoto et al., 2010).

In the summer of 2017, intense wildfires spread in the west and north of Canada. By mid-August, the burnt area had grown to almost $9000 \mathrm{~km}^{2}$ in British Columbia, which broke the record set in 1958 (see https://www.nceo.ac.uk/article/ the-2017-canadian-wildfires-a-satellite-perspective/, last access: 15 January 2019). The severe wildfires generated strong pyro-cumulonimbus clouds, which were recorded by the satellite imagery MODIS (Moderate Resolution Imaging Spectrometer). The GOES-15 (Geostationary Operational Environmental Satellite) detected five pyro-cumulonimbus clouds in British Columbia on 12 August 2017 (see https: //pyrocb.ssec.wisc.edu, last access: 15 January 2019). Smoke plumes in the troposphere and lower stratosphere were observed by several European lidar stations in August and September 2017. Ansmann et al. (2018) and Haarig et al. (2018) observed stratospheric and tropospheric smoke layers originating from Canadian wildfires on 21-23 August 2017 in Leipzig, Germany. The maximum extinction coefficient of the smoke layers reached $0.5 \mathrm{~km}^{-1}$, about 20 times higher than the observation 10 months after the eruption of the Pinatubo volcano in 1991 (Ansmann et al., 1997). Khaykin et al. (2018) reported Canadian smoke layers in the stratosphere over southern France in August 2017 and they found that the smoke plumes can travel the whole globe (at middle latitudes) in about 3 weeks.

Reoccurring aerosol layers in the troposphere and lower stratosphere were detected by the lidar systems in northern France during 19 August and 12 September 2017. In this study, we present the stratospheric smoke observations from two French lidar stations: Lille (lat 50.612, long 3.142, $60 \mathrm{~m}$ a.s.1.) and Palaiseau (lat 48.712, long 2.215, $156 \mathrm{~m}$ a.s.l.), and a mobile lidar system. Satellite measurements from multiple sensors, including UVAI (ultraviolet aerosol index) from the OMPS NM (Ozone Mapping and Profiler Suite, Nadir Mapper), CO (carbon monoxide) concentration from AIRS (Atmospheric Infrared Sounder), and backscatter coefficient and depolarization ratio profiles from CALIPSO (Cloud-Aerosol Lidar and Infrared Pathfinder Satellite Observations) help identify the source and the transport pathway of the smoke layers. This study is focused on the retrieval of the aerosol optical and microphysical properties using lidar measurements. Further, the radiative effect of the smoke layer is presented.

\section{Methodology}

\subsection{Lidar data processing}

In this subsection, we present the method for processing lidar measurements and the error estimation is presented in the Appendix. The Raman lidar technique (Ansmann et al., 1992) allows an independent calculation of extinction and backscatter coefficients. When the nitrogen Raman signal is not available, the Klett method (Klett, 1985) is used to calculate the extinction and backscatter coefficients, based on an assumption of the aerosol lidar ratio.

In this study, the stratospheric aerosol layers are at high altitudes at which the signal-to-noise ratio of Raman channels is not sufficient to obtain a high-quality extinction profile; therefore, we choose the Klett method.

To reduce the dependence of Klett inversion on the assumption of lidar ratio, we use a pre-calculated optical depth of the stratospheric aerosol layer as an additional constraint. We test a series of lidar ratios in the range of 10-120 sr and apply independent Klett inversion with each lidar ratio at a step of $0.5 \mathrm{sr}$. The integral of the extinction coefficient over the stratospheric layer, expressed below, is compared with the pre-calculated optical depth.

$$
\tau^{i}(\lambda)=\int_{r_{\text {base }}}^{r_{\text {top }}} \alpha_{a}(\lambda, r) \mathrm{d} r
$$

where $\tau^{i}$ is the integral of extinction coefficient $\alpha_{a}$, derived from Klett inversion. $r$ is the distance, the subscripts "top" and "base" represent the top and base of the stratospheric aerosol layer, and $\lambda$ is the lidar wavelength.

The pre-calculated optical depth is derived from the elastic channel at 355 and $532 \mathrm{~nm}$. The method is widely used in cirrus cloud studies (Platt, 1973; Young, 1995). By comparing the lidar signal with the molecular backscattered lidar signal, we found there is only molecular scattering below and above the smoke plumes. So we can calculate the optical depth of the smoke plumes as below:

$$
\tau^{u}(\lambda)=\frac{1}{2} \ln \frac{\bar{P}_{\text {base }}(\lambda) r_{\text {base }}^{2} \beta_{\mathrm{m}}\left(\lambda, r_{\text {top }}\right)}{\bar{P}_{\text {top }}(\lambda) r_{\text {top }}^{2} \beta_{\mathrm{m}}\left(\lambda, r_{\text {base }}\right)}-\int_{r_{\text {base }}}^{r_{\text {top }}} \alpha_{\mathrm{m}}(\lambda, r) \mathrm{d} r,
$$

where $\tau^{u}$ is the optical depth of the stratospheric smoke layers. $\bar{P}_{\text {top }}$ and $\bar{P}_{\text {base }}$ represent the mean lidar signal at the top and the base of the stratospheric layer. $\alpha_{\mathrm{m}}$ and $\beta_{\mathrm{m}}$ are the molecular extinction and backscatter coefficients. We calculate the lidar signal mean within a window of $0.5 \mathrm{~km}$ at the top and the base of the aerosol layer to get $\bar{P}\left(r_{\text {top }}, \lambda\right)$ and $\bar{P}\left(r_{\text {base }}, \lambda\right)$. We use this method to estimate the optical depth of the stratospheric layer for LILAS and IPRAL measurements. The lidar ratio leading to the best agreement of $\tau^{i}$ and $\tau^{u}$ is accepted as the retrieved lidar ratio of the stratospheric aerosol layer. We apply Klett inversion only to the stratospheric aerosol layer, from $1 \mathrm{~km}$ below the layer base to $1 \mathrm{~km}$ above the layer top. Therefore, the impact of tropospheric aerosols is excluded. Compared to the Raman method, the extinction and backscatter coefficients calculated from the Klett method are not independent because of the assumed 
vertically constant aerosol lidar ratio. But in this study, the smoke particles are well mixed, so the vertical variation in lidar ratio is expected to be not significant. Additionally, using the Klett method avoids the effects of vertical smoothing that occur to the Raman derived extinction profile.

The particle linear depolarization ratio, $\delta_{\mathrm{p}}$, is written as

$\delta_{\mathrm{p}}=\frac{R \delta_{\mathrm{v}}\left(\delta_{\mathrm{m}}+1\right)-\delta_{\mathrm{m}}\left(\delta_{\mathrm{v}}+1\right)}{R\left(\delta_{\mathrm{m}}+1\right)-\left(\delta_{\mathrm{v}}+1\right)}$,

where $R$ is the backscatter ratio, $\delta_{\mathrm{v}}$ is the volume linear depolarization ratio, and $\delta_{\mathrm{m}}$ is the molecular depolarization ratio. $R$ is defined as the ratio of the total backscatter coefficient to the molecular backscatter coefficient. $\delta_{\mathrm{m}}=0.004$ is used in the calculation of particle linear depolarization ratio. $\delta_{\mathrm{v}}$ is the ratio of the perpendicularly backscattered signal to the parallel backscattered signal, multiplied by a calibration coefficient. The depolarization calibration is designed to calibrate the electro-optical ratio between the perpendicular and parallel channels and is performed following the procedure proposed by Freudenthaler et al. (2009). The particle linear depolarization ratio is a parameter related to the shape of aerosol particles, and it is usually used in the lidar community for aerosol typing. The particle linear depolarization ratio of spherical particles is zero. For irregular-shaped particles, for example ice particles in cirrus clouds, the measured particle linear depolarization is about 0.40 (Sassen et al., 1985; Veselovskii et al., 2017).

\subsection{Aerosol inversion and radiative forcing estimation}

The $3 \beta+2 \alpha$ from lidar observations can be inverted to obtain particle microphysical parameters. The regularization algorithm is used to retrieve size distribution, wavelengthindependent complex refractive indices, particle number, and surface and volume concentrations (Müller et al., 1999; Veselovskii et al., 2002). We apply GRASP (Generalized Retrieval of Aerosol and Surface Properties) to calculate the DRF (direct radiative forcing) effect of the stratospheric aerosol layer. GRASP is the first unified algorithm developed for characterizing atmospheric properties gathered from a variety of remote-sensing observations. Depending on the input data, GRASP can retrieve columnar and vertically resolved aerosol properties and surface reflectance (Dubovik et al., 2014). As a branch of the GRASP algorithm, GARRLiC (Generalized Aerosol Retrieval from Radiometer and Lidar Combined data, called GARRLiC/GRASP hereafter) algorithm was developed for the inversion of coincident singleor multi-wavelength lidar and sun photometer measurements (Lopatin et al., 2013; Bovchaliuk et al., 2016). The two main modules of GARRLiC/GRASP are the forward model and numerical inversion module. The forward module simulates the atmospheric radiation by using radiative transfer and by accounting for the interaction between light and trace gases, aerosols, and underlying surfaces. The aerosol scattering properties in the atmosphere are represented by one or two aerosol components, whose optical properties can be described using a mixture of spheres and spheroids and are vertically independent. The vertically resolved optical properties, such as the extinction and backscatter coefficients etc., measured by lidar, are described by varying the aerosol vertical concentration. The forward model includes a radiative transfer model in order to simulate multiple types of observations. The radiative transfer equation in GARRLiC/GRASP is solved using this parallel plane approximation. The atmosphere is divided into a series of parallel planes and the optical properties of each parallel plane can be represented by the input parameters. The radiative transfer model is based on the study of Lenoble et al. (2007). The numerical inversion module follows the multi-term least-squares method strategy and derives a group of unknown parameters that fits the observations.

In this study, we apply the forward model of GARRLiC/GRASP to estimate the forcing effect of the observed stratospheric plume in contrast to a standard Rayleigh atmosphere. The input parameters for DRF are the retrieved aerosol microphysical properties from the regularization algorithm, including the size distribution, the complex refractive indices, and the assumed sphere fraction; the aerosol vertical distribution of the stratospheric plume; and surface BRDF (bidirectional reflectance distribution function) parameters. The forward model of GARRLiC/GRASP can produce downward and upward broadband flux, covering the $0.2-4.0 \mu \mathrm{m}$ spectrum, at vertical levels specified by the users. Hence, we can calculate the DRF and the heating rate specific to smoke plume.

\section{Ground-based and satellite observations}

\subsection{Simultaneous lidar and sun photometer observations}

LILAS (Lille Lidar Atmospheric Study) is a multiwavelength Raman lidar (Bovchaliuk et al., 2016; Veselovskii et al., 2016) operated at LOA (Laboratoire d'Optique Atmosphérique, Lille, France). The LILAS system is transportable and has three elastic channels (355, 532 , and $1064 \mathrm{~nm}$ ), with the capability of measuring the depolarization ratios at these wavelengths. Further, it has three Raman channels at 387, 408, and $530 \mathrm{~nm}$. The IPRAL system (IPSL Hi-Performance multi-wavelength Raman Lidar; Bravo-Aranda et al., 2016; Haeffelin et al., 2005) is a multi-wavelength Raman lidar operated at SIRTA (Site Instrumental de Recherche par Télédétection Atmosphérique, Palaiseau, France). The distance between the two systems is around $300 \mathrm{~km}$. Lidar IPRAL has the same elastic channels as LILAS, but the three Raman channels are 387, 408 , and $607 \mathrm{~nm}$. In the IPRAL system, the depolarization ratio is only measured at $355 \mathrm{~nm}$. The two lidar systems were operated independently and both observed reoccur- 
ring smoke layers in the lower stratosphere during the period from 19 August to 12 September 2017. In addition, sun photometer measurements are available at Lille and Palaiseau, which are both affiliated stations of AERONET (AEROsol RObotic NETwork). The LILAS and IPRAL lidar systems are affiliated with EARLINET (European Aerosol Research Lidar Network) (Bösenberg et al., 2003; Böckmann et al., 2004; Matthais et al., 2004; Papayannis et al., 2008; Pappalardo et al., 2014). Both systems perform regular measurements and follow the standard EARLINET data quality check and calibration procedures (Freudenthaler et al., 2018).

On 29 August, three lidar systems in northern France simultaneously observed a stratospheric aerosol layer. The three lidar systems are LILAS, IPRAL, and a single wavelength (532 nm) CIMEL micro-pulse lidar, which is set up in a light mobile system, MAMS (Mobile Aerosol Monitoring System; Popovici et al., 2018), to explore aerosol spatial variability. MAMS was traveling between Palaiseau and Lille on 28 and 29 August. MAMS is equipped with a mobile sun photometer, PLASMA (Photomètre Léger Aéroporté pour la Surveillance des Masses d'Air, Karol et al., 2013), capable of measuring columnar aerosol optical depth (AOD) along the route. The configuration of the three lidar systems is summarized in Table 1.

Figure 1 shows the normalized lidar range-corrected signals and columnar AOD at $532 \mathrm{~nm}$ derived from sun photometer measurements on 29 August 2017. The aerosol layers in the lower stratosphere, stretching from 16 to $20 \mathrm{~km}$, were detected by the three lidars. The IPRAL lidar system in Palaiseau detected the aerosol layer in the range of 16$20 \mathrm{~km}$ on 29 August. The columnar AOD showed no significant variations, staying between 0.30 and 0.40, from 10:00 to 16:00 UTC and started decreasing from 17:00 UTC. Along the route from Palaiseau to Lille, MAMS lidar observed a layer between 16 and $20 \mathrm{~km}$ consisting of two well-separated layers. The columnar AOD was very stable, around 0.40, all along the route from Palaiseau to Lille. Lidar LILAS in Lille observed a shallow layer between 18 and $20 \mathrm{~km}$ at about 08:00 UTC on 29 August. The thickness of the layer increased to $4 \mathrm{~km}$ until 16:00 UTC. The columnar AOD increased from 0.20 to 0.40 from 08:00 to 14:00 UTC. The lidar quick look indicated that the aerosol content in the lower troposphere did not show significant variations during 08:00 and 12:00 UTC, so the increased optical depth, 0.2 , came mainly from the contribution of the stratospheric aerosol layer.

Figure 2 shows the lidar range-corrected signal at $1064 \mathrm{~nm}$ on 24-25 August 2017. The plume between 17 and $18.5 \mathrm{~km}$ is the smoke layer. Due to cirrus clouds and low clouds in the troposphere, the lidar signals in the plume are interrupted. In the nighttime, the plume base is stable at about $17 \mathrm{~km}$. Just starting from the sunrise time at 04:51 UTC, a gradual and obvious ascent is observed. In 3-4 h, the plume base ascended by about $0.6 \mathrm{~km}$. Between 10:00 and 16:00 UTC, the plume base stayed stable. The ascent of smoke plume was also presented in Ansmann et al. (2018) and Khaykin et al. (2018). Khaykin et al. (2018) mentioned that the plume ascended very fast during the first few days after being injected into the troposphere. Based on the observation in Fig. 2, we derived the ascent rate of approximately $2.1-2.8 \mathrm{~km}$ per day, considering that the sunshine duration is $14 \mathrm{~h}$ (according to the latitude of Lille site) and that the vertical speed of the plume is constant. Ansmann et al. (2018) explained that the ascent of the plume may be related to the absorption of sootcontaining aerosols and the wind velocity in the stratosphere. Figure 2 shows that the plume does not continuously ascend in the daytime. One possible explanation we infer is that the self-heating and the wind shear reached an equilibrium point in the plume, so it moved neither upward nor downward.

\subsection{Radiosonde measurements}

We take the radiosonde measurements from two stations closest to the lidar sites: Trappes $\left(48.77^{\circ} \mathrm{N}, 1.99^{\circ} \mathrm{E}\right.$, France) and Beauvechain $\left(50.78^{\circ} \mathrm{N}, 4.76^{\circ} \mathrm{E}\right.$, Belgium). Trappes is about $20 \mathrm{~km}$ from Palaiseau and Beauvechain is $120 \mathrm{~km}$ from Lille. Considering the large spatial distribution of the stratospheric aerosols, it is obvious that the radiosonde passed through this stratospheric smoke layer. Figure 3 shows the temperature at 00:00 and 12:00 UTC on 29 August for Trappes and 21:00 UTC on 29 August for Beauvechain. To compare, we plot the temperature profile of Trappes at 12:00 UTC on 21 August, when no stratospheric aerosol layers presented. The temperature profiles clearly show an enhancement between 16 and $20 \mathrm{~km}$, which coincides with the altitude at which the stratospheric plumes appear. The spatial-temporal occurrence of this temperature enhancement and the stratosphere plume at two independent stations indicate that they are directly correlated. Fromm et al. (2005, 2008) also presented temperature increase in the stratospheric smoke layers.

\subsection{MODIS measurements}

MODIS is a key instrument onboard the Terra and Aqua satellites. Terra MODIS and Aqua MODIS view the entire Earth's surface every 1 to 2 days. Several episodes of Canadian wildfires have been observed by MODIS since early July 2017. On 12 August, MODIS observed a thick grey plume arising from British Columbia in the west of Canada (not shown; please see the web page of WorldView: https://worldview.earthdata.nasa.gov, last access: 15 January 2019). Figure 4 shows the Earth's true color image overlaid with the fires and thermal anomalies on $15 \mathrm{Au}-$ gust 2017 when the plumes had spread over a large area. The region marked with the green dashed line is a huge visible smoke plume and in its southwest MODIS detected a belt of fire spots. Additionally, during the week of 13-19 August, MODIS (see https://worldview.earthdata.nasa.gov, last 
Table 1. Three involved lidar systems and their configuration and locations.

\begin{tabular}{lll}
\hline Name & Configuration & Location \\
\hline \multirow{2}{*}{ LILAS } & $\begin{array}{l}\text { Elastic + depolarization: 355, 532, 1064 nm } \\
\text { Raman: 387, 408 (water vapor), 530 } \mathrm{nm}\end{array}$ & LOA, Lille \\
\hline \multirow{2}{*}{ IPRAL } & $\begin{array}{l}\text { Elastic: } 355 \text { (depolarization), 532, 1064 nm } \\
\text { Raman: 387, 408 (water vapor), 608 nm }\end{array}$ & SIRTA, Palaiseau \\
\hline \multirow{2}{*}{ MAMS lidar } & Elastic: $532 \mathrm{~nm}$ & $\begin{array}{l}\text { from Palaiseau } \\
\text { to Lille (29 August) }\end{array}$ \\
\hline
\end{tabular}

(a)

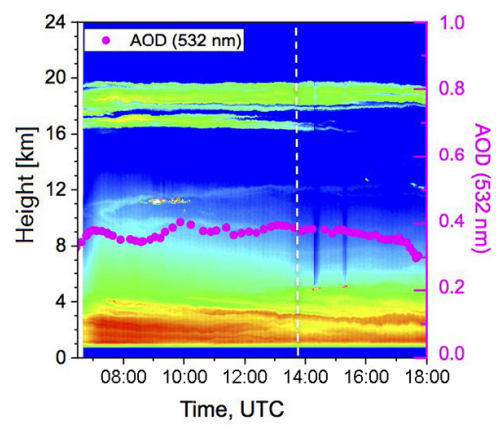

(b)

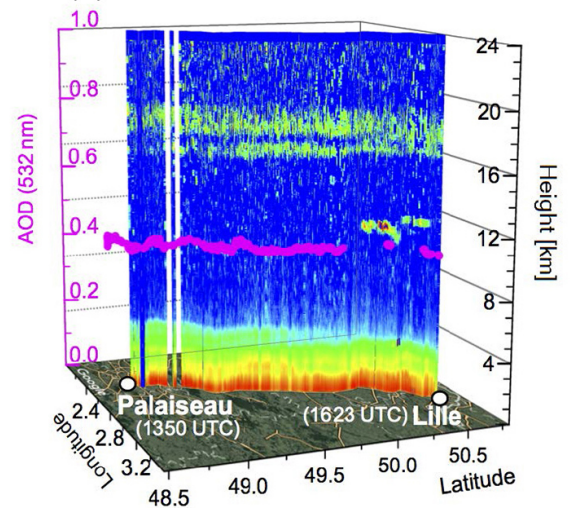

(c)

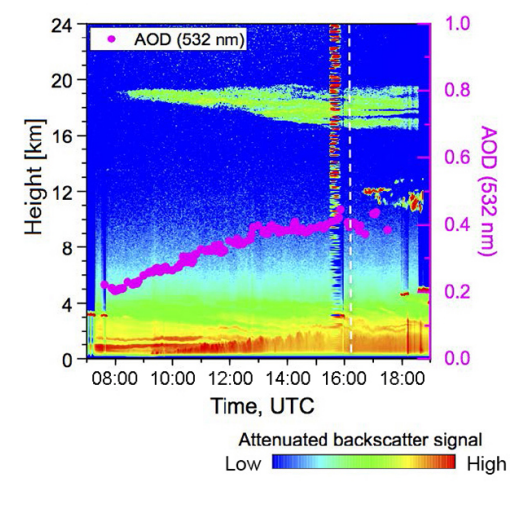

Figure 1. Lidar range-corrected signal and columnar AOD from the sun photometer at $532 \mathrm{~nm}$ on 29 August 2017. (a) IPRAL system in Palaiseau. (b) MAMS lidar en route from Palaiseau to Lille. (c) LILAS in Lille. Columnar AOD measurements are interpolated from AERONET (Lille and Palaiseau) and PLASMA (mobile system) measurements. MAMS started from Palaiseau at 13:53 UTC and arrived in Lille at 16:23 UTC. The departure and arriving times are indicated in (a) and (c) with the dashed white lines.

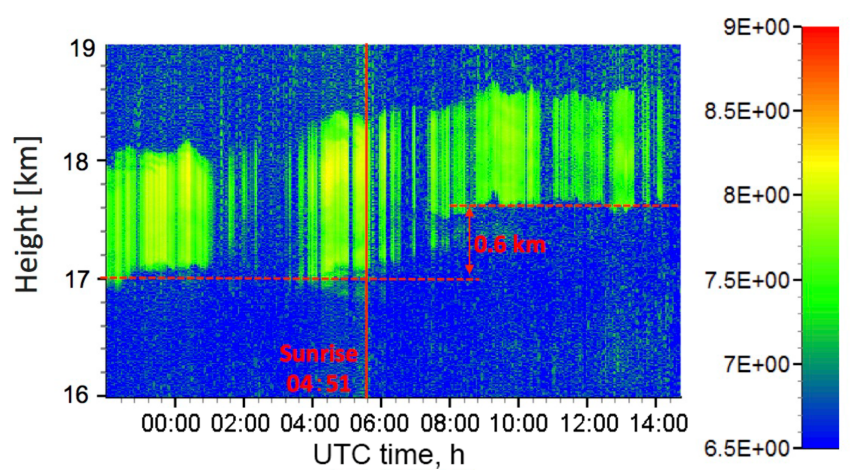

Figure 2. Lidar range-corrected signal at $1064 \mathrm{~nm}$ on $24-25 \mathrm{Au}-$ gust 2017 measured by LILAS. The solid red line indicates the sunrise time. The two dashed red lines point out the approximate layer base before and after the sunrise. The sunrise and sunset times are 04:51 and 20:47 UTC, respectively. The corresponding daytime duration is about $14 \mathrm{~h}$. access: 15 January 2019) observed a widespread cloud coverage over Canada and showed that cloud layers were overshadowed by the smoke plumes, meaning that the plumes were lofted above the cloud layers, as shown in Fig. 4.

\subsection{OMPS NM UVAI maps}

UVAI is a widely used parameter in characterizing UVabsorbing aerosols, such as desert dust, carbonaceous aerosols coming from anthropogenic biomass burning, wildfires, and volcanic ash. The UVAI is determined using the 340 and $380 \mathrm{~nm}$ wavelength channels and is defined as

$\mathrm{UVAI}=-100 \times\left\{\log _{10}\left[\frac{I_{340}}{I_{380}}\right]_{\text {meas }}-\log _{10}\left[\frac{I_{340}}{I_{380}}\right]_{\text {calc }}\right\}$,

where $I_{340}$ and $I_{380}$ are the backscattered radiance at 340 and $380 \mathrm{~nm}$. The subscript "meas" represents the measurements and "calc" represents the calculation using a radiative transfer model for pure Rayleigh atmosphere. The UVAI is defined so that positive values correspond to UV-absorbing aerosols and negative values correspond to non-absorbing aerosols (Hsu et al., 1999). The OMPS NM on board the Suomi NPP (National Polar-orbiting Partnership) is designed to measure the total column ozone using backscattered UV 


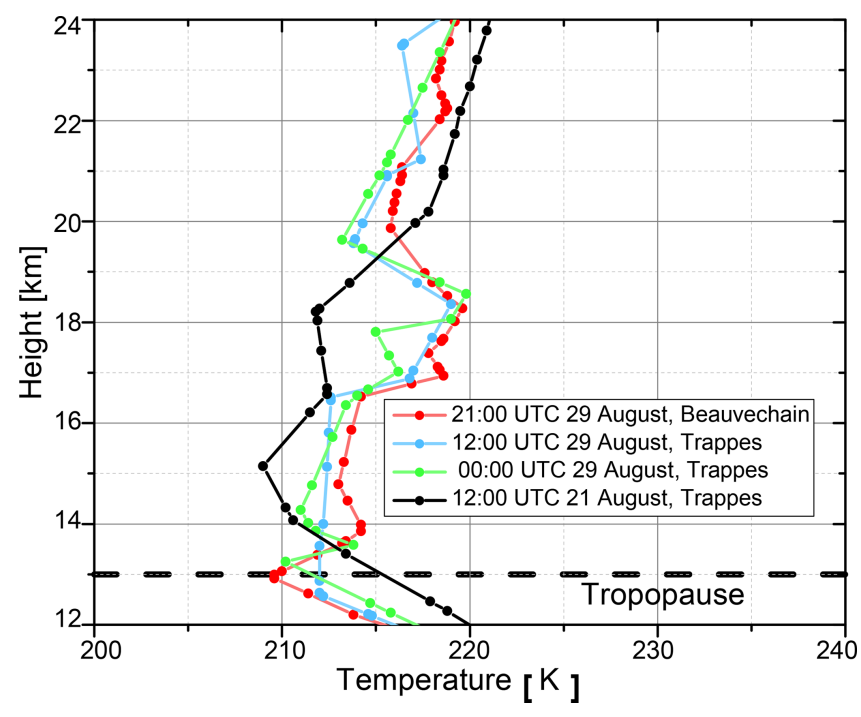

Figure 3. Temperature profiles from the radiosonde measurements. The green and cerulean lines are the temperature profiles of Trappes at 00:00 and 12:00 UTC on 29 August 2017. The red line shows the Beauvechain data at 21:00 UTC on 29 August 2017. The black line is for 12:00 UTC on 21 August in Trappes. The horizontal dashed black line at $13 \mathrm{~km}$ represents the approximate position of the tropopause.

radiation between 300 and $380 \mathrm{~nm}$. A $110^{\circ}$ FOV (field-ofview) telescope enables full daily global coverage (McPeters et al., 2000; Seftor et al., 2014). Figure 5 shows the evolution of UVAI from OMPS NM (Jaross, 2017) every 2 days from 11 to 29 August 2017. The evolution of the UVAI during this event has also been shown in the study of Khaykin et al. (2018). A plume with relatively high UVAI first occurred over British Columbia on 11 August, and the intensity of the plume was moderate. An obvious increase in UVAI from 11 to 13 August was observed over the northwest of Canada. It is a clear indication that the events on 12 August were responsible for the increase in UVAI. From 13 to 17 August, the plume spread in the northwest-southeast direction and the UVAI in the center of the plume reached 10. On $19 \mathrm{Au}-$ gust, the plume center reached the Labrador Sea and the forefront of the plume reached Europe. From 21 to 29 August, the UVAI in the map was much lower than the previous week. During this period, we can still distinguish a plume propagating eastward from the Atlantic to Europe, with the UVAI damping during the transport. Figure 5e-j show that Europe was overshadowed by the high-UVAI plume during 19 and 29 August.

\subsection{AIRS CO maps}

AIRS is a continuously operating cross-track scanning sounder on board NASA's Aqua satellite launched in May 2002. AIRS covers the 3.7 to $16 \mu \mathrm{m}$ spectral range with 2378 channels and a $13.5 \mathrm{~km}$ nadir FOV (Susskind et al., 2014;
Kahn et al., 2014). The daily coverage of AIRS is about $70 \%$ of the globe. AIRS is designed to measure the water vapor and temperature profiles. It includes the spectral features of the key carbon trace gases, $\mathrm{CO}_{2}, \mathrm{CH}_{4}$, and $\mathrm{CO}$ (Haskins and Kaplan, 1992). The current CO product from AIRS is very mature because the spectral signature is strong and the interference of water vapor is relatively low (McMillan et al., 2005). CO, as a product of the burning process, can be taken as a tracer of biomass burning aerosols (Andreae et al., 1988) due to its relatively long lifetime of 0.5 to 3 months. CO can also originate from anthropogenic sources, for example engines of vehicles (Vallero, 2014). In August 2017, the wildfire activities were so intense that the $\mathrm{CO}$ plumes rising from the fire region were much more significant than the background. This strong contrast makes $\mathrm{CO}$ a good tracer for the transport of the smoke plumes.

Figure 6 shows the evolution of the total column CO concentration (Texeira, 2013) every 2 days during the period of 11 to 29 August 2017. CO concentration strongly increased in the west and north of Canada from 11 to 13 August, similar to the UVAI shown in Fig. 5. The forefront of the CO plume reached the west and north of Europe since $19 \mathrm{Au}-$ gust. We find that the spatial distribution and temporal evolution of $\mathrm{CO}$ are strongly co-related with the UVAI. This correlation is very evident before 21 August. After 21 August, the correlation became weaker, for the UVAI in North America was decreasing fast while the $\mathrm{CO}$ concentration remained almost unchanged or decreased much more slowly. This is possibly due to the longer lifetime of CO compared to UVAI. Combing the MODIS image and the UVAI and CO spatialtemporal evolution, we conclude that the aerosol plumes observed in Europe were smoke transported from Canada.

\subsection{CALIPSO measurements}

CALIPSO measurements provide a good opportunity to investigate the vertical structure of the plumes and trace back the transport of the plumes. CALIPSO measures the backscattered signal at 532 and $1064 \mathrm{~nm}$. One parallel channel and one perpendicular channel are coupled to derive the particle linear depolarization ratio at $532 \mathrm{~nm}$. Figure $7 \mathrm{a}-\mathrm{f}$ present the profiles of the backscatter coefficient and particle linear depolarization ratio at $532 \mathrm{~nm}$, corresponding to the six locations a-f in Fig. 4. These data were obtained from the NASA Langley Research Center Atmospheric Science Data Center. The six locations are intentionally selected, falling in the region with elevated UVAI and CO concentration and following the transport pathway of the plume (in Figs. 5 and 6) from Canada to Europe. Figure 7 shows the enhancements of backscatter in the upper troposphere and lower stratosphere. Aerosol and cloud are both possible causes of the backscatter enhancements and can be distinguished by using the particle depolarization ratio. We have examined the temperature profiles over several sites in North America in August 2017 and found that, above $10 \mathrm{~km}$, the temperature drops below 


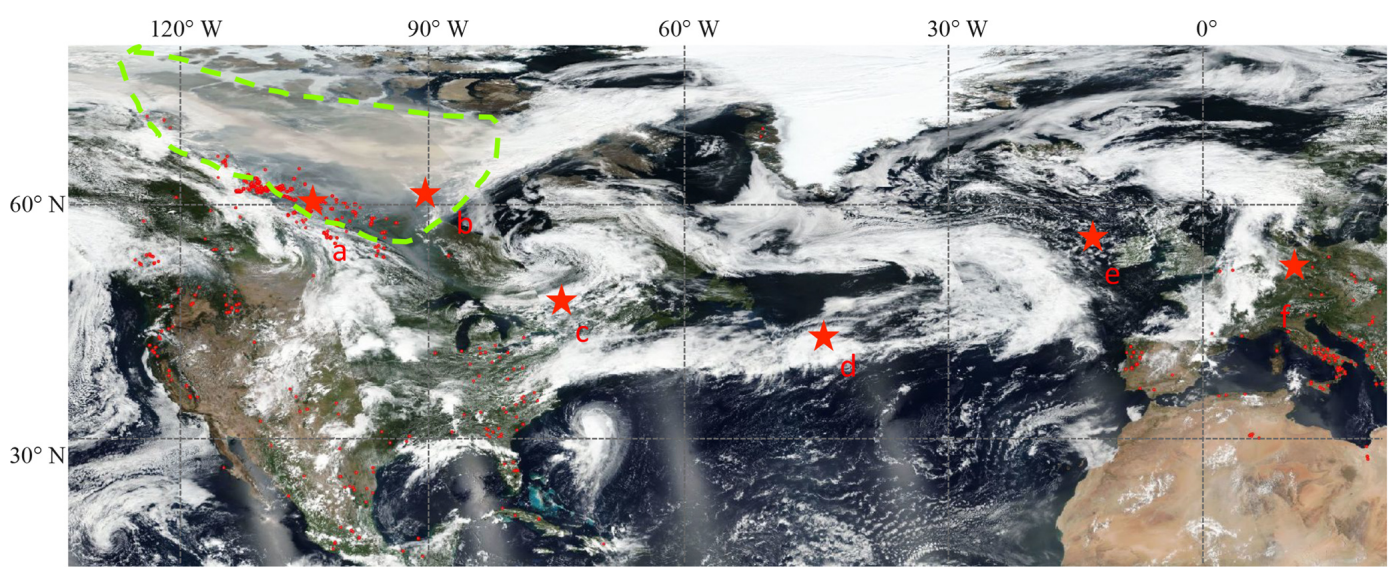

Figure 4. The corrected surface reflectance overlaid with fire and thermal anomalies from MODIS (15 August 2017). The region marked with the dashed green line in the northwest indicated a plume generated by fire activities. Six locations (labeled as red stars) on the tracks of CALIPSO are selected: (a) $\left(61.47^{\circ} \mathrm{N}, 106.44^{\circ} \mathrm{W}\right)$, (b) $\left(62.79^{\circ} \mathrm{N}, 91.54^{\circ} \mathrm{W}\right)$, (c) $\left(46.97^{\circ} \mathrm{N}, 72.22^{\circ} \mathrm{W}\right),(\mathbf{d})\left(42.27^{\circ} \mathrm{N}, 42.08^{\circ} \mathrm{W}\right)$, (e) $\left(55.97^{\circ} \mathrm{N}, 12.54^{\circ} \mathrm{W}\right)$, and (f) $\left(52.37^{\circ} \mathrm{N}, 13.47^{\circ} \mathrm{E}\right)$. The corresponding overpass date is $14,15,17,19,21$, and 23 August 2017.

$-38^{\circ} \mathrm{C}$; at this temperature clouds consist mainly of ice crystals. The particle depolarization ratio is usually no less than 0.40 for ice cloud and from a few percent to about 0.40 for mixed-phase cloud.

Figure $7 \mathrm{a}$ and $\mathrm{b}$ show the aerosol layers observed on 14 and 15 August over the north of Canada; both locations lay in the area where MODIS observed a smoke plume on $15 \mathrm{Au}-$ gust (Fig. 4) and the area with high UVAI and CO concentration. The particle linear depolarization ratio is about 0.05 in Fig. $7 \mathrm{a}$ and 0.10 in Fig. $7 \mathrm{~b}$, meaning that it is an aerosol layer instead of ice or mixed-phase cloud. Figure $7 \mathrm{c}$ and $\mathrm{f}$ show stratospheric layers detected at $10-20 \mathrm{~km}$ in height, with the depolarization varying from 0.10 to 0.18 . The lower layer at about $9 \mathrm{~km}$ in Fig. $7 \mathrm{~d}$ has a depolarization ratio between 0.20 and 0.45 (median 0.32), which falls into the category of ice or mixed-phase clouds. Profiles in Fig. $7 \mathrm{f}$ were captured over Berlin at 01:29 UTC on 23 August. About $150 \mathrm{~km}$ to the southwest, a lidar in Leipzig measured stratospheric smoke layers (Haarig et al., 2018). The particle depolarization ratio of CALIPSO at $532 \mathrm{~nm}$ on 23 August is consistent with ground-based lidar measurements in Lille and Leipzig, which will be presented in Sect. 4. It should be noted that aerosol types of the plumes in Fig. 7 are quite uncertain in the CALIPSO product. These layers are classified into scattered aerosol types, such as polluted dust, elevated smoke, and volcanic ash. This misclassification could introduce some extent of errors to the backscatter profile and particle depolarization profiles.

\section{Results and analysis}

\subsection{Overview of retrieved optical parameters}

We selected and averaged the lidar measurements in 10 time intervals, among which five periods are from the LILAS sys- tem in Lille: 22:00 (24 August)-00:30 UTC (25 August); 13:00-16:00 UTC, 16:00-18:00 UTC (29 August); 20:0023:00 UTC (31 August); and 23:00 (31 August)-02:00 UTC (1 September); two intervals are from the IPRAL system in Palaiseau: 16:00-18:00 and 19:20-21:20 UTC (28 August). Three intervals are from the mobile lidar in the MAMS system (29 August): 14:00-15:00 UTC (corresponding spatially to a $100 \mathrm{~km}$ distance from Palaiseau to Compiègne), 15:0015:45 UTC (100 km on the route from Compiègne to Arras), and 16:15-16:30 UTC at Lille.

Figure 8 shows the optical depth of the stratospheric layer varying from 0.05 to 0.23 (at $532 \mathrm{~nm}$ ). The spectral dependence of the optical depth of 355 and $532 \mathrm{~nm}$ is very weak. The maximal optical depth of the stratospheric layer was observed in the afternoon of 29 August, between 16:00 and 18:00 UTC. The LILAS system observed AOD of $0.20 \pm$ 0.04 at $355 \mathrm{~nm}$ and $0.21 \pm 0.04$ at $532 \mathrm{~nm}$. As discussed in Sect. 3.1, the columnar AOD at $532 \mathrm{~nm}$ from AERONET increased by about 0.20 after the presence of the stratospheric layer, which agrees well with the derived optical depth of the stratospheric layer. The minimum of the optical depth appeared in the night of 31 August 2017, giving $0.04 \pm 0.02$ at $355 \mathrm{~nm}$ and $0.05 \pm 0.02$ at $532 \mathrm{~nm}$. The optical depth of the stratospheric layer along the route, observed by MAMS, is as follows: 0.19 over a distance of $100 \mathrm{~km}$ north from Palaiseau, 0.23 along $100 \mathrm{~km}$ of the middle of the transect from Compiègne to Arras, and 0.22 when arriving at Lille.

Due to the insufficient signal-to-noise ratio above the stratospheric plume, the MAMS lidar measurements are processed using the Klett method and constrained by the columnar AOD measured by the PLASMA sun photometer. Klett inversion is performed on the lidar profile from the surface to the top of the stratospheric layer, assuming a vertically independent lidar ratio. The optical depth of the stratospheric smoke layer is then calculated from the integral of the ex- 


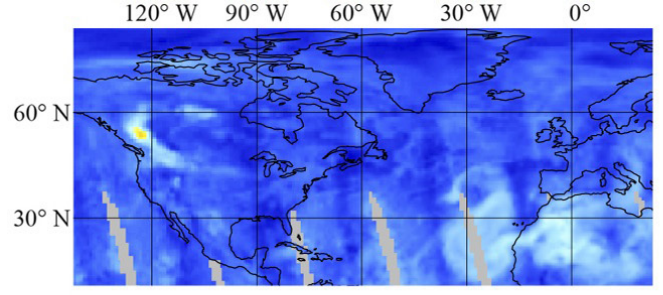

(a) 11 August 2017

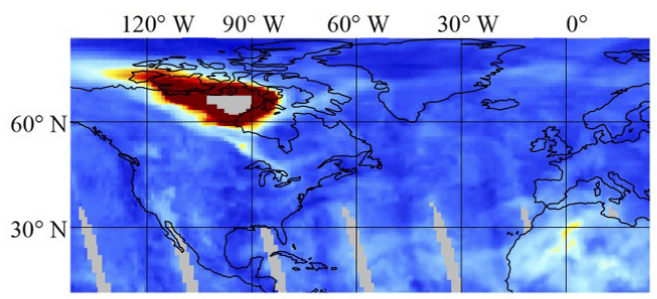

(c) 15 August 2017

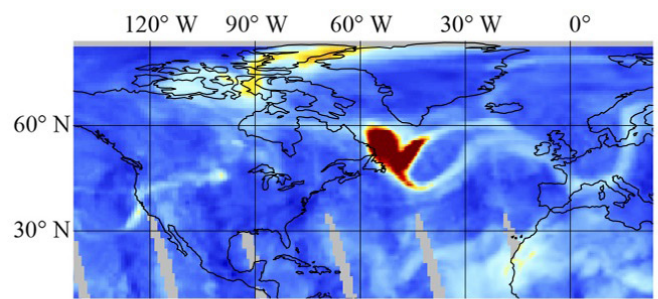

(e) 19 August 2017

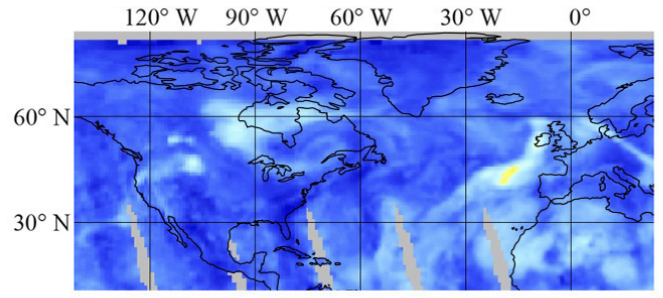

(g) 23 August 2017

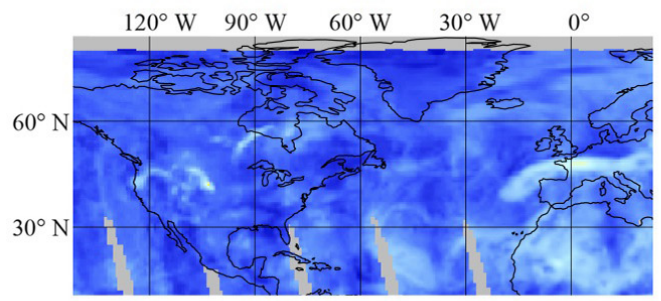

(i) 27 August 2017

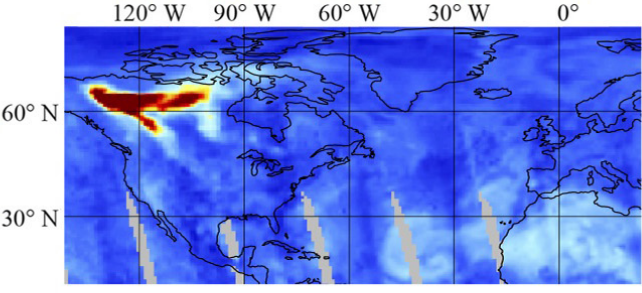

(b) 13 August 2017

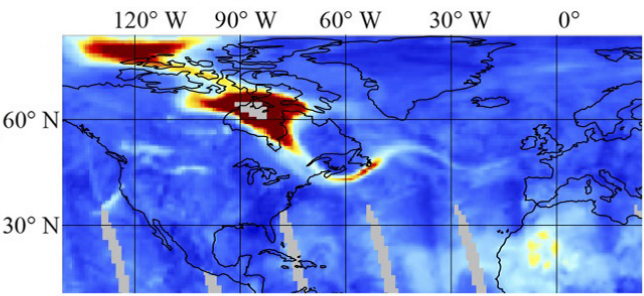

(d) 17 August 2017

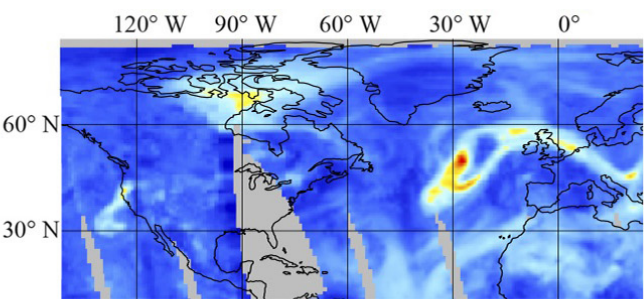

(f) 21 August 2017

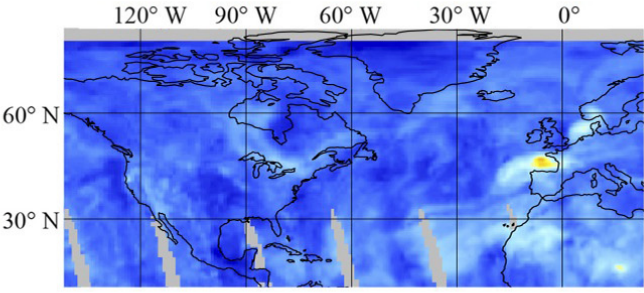

(h) 25 August 2017

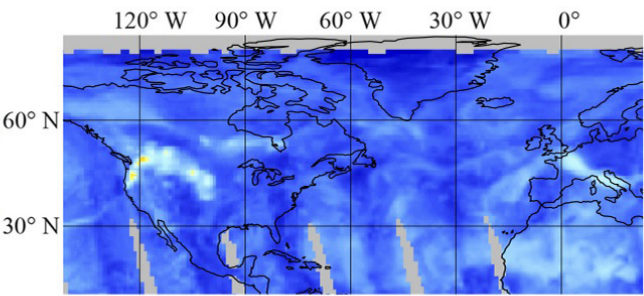

(j) 29 August 2017

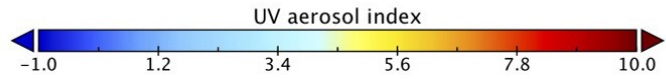

Figure 5. OMPS NM daily UVAI products from 11 to 29 August 2017. The results are plotted every 2 days. Grey indicates areas with no retrievals. 


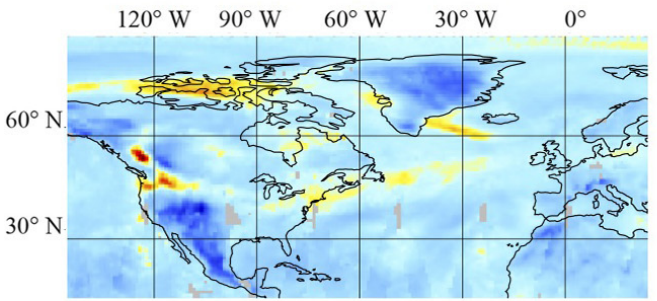

(a) 11 August 2017

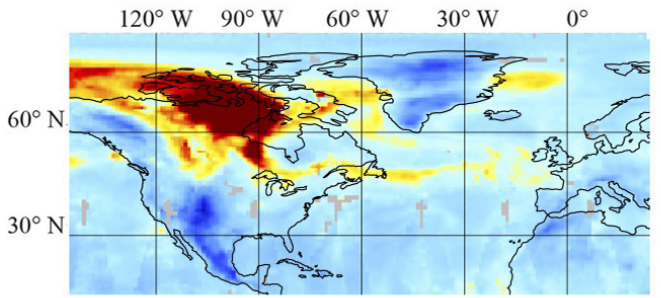

(c) 15 August 2017

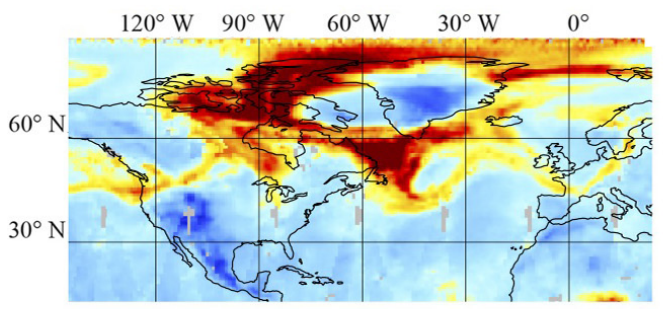

(e) 19 August 2017

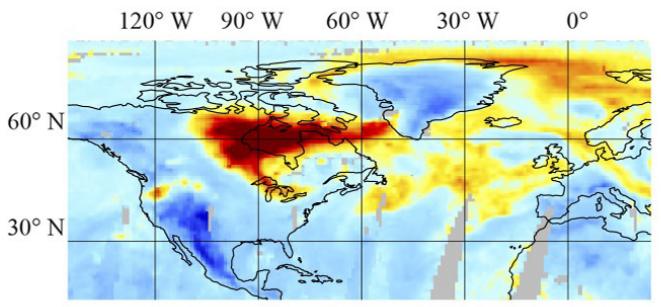

(g) 23 August 2017

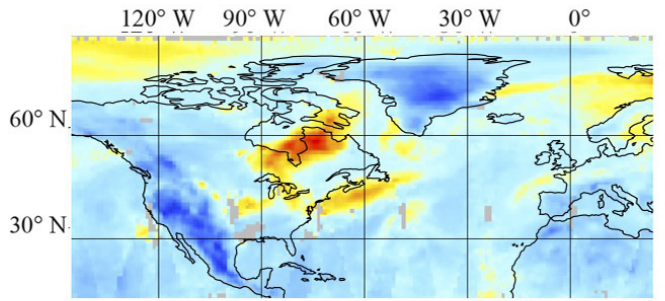

(i) 27 August 2017

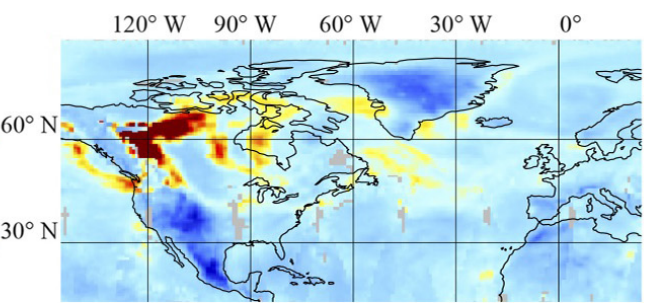

(b) 13 August 2017

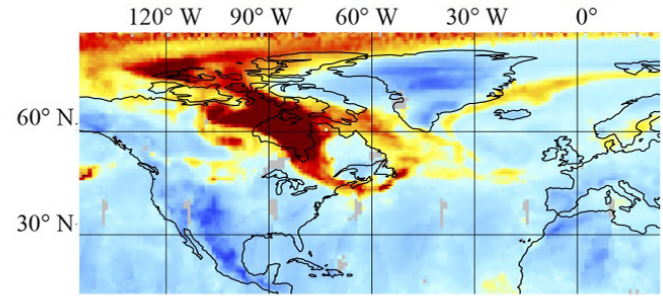

(d) 17 August 2017

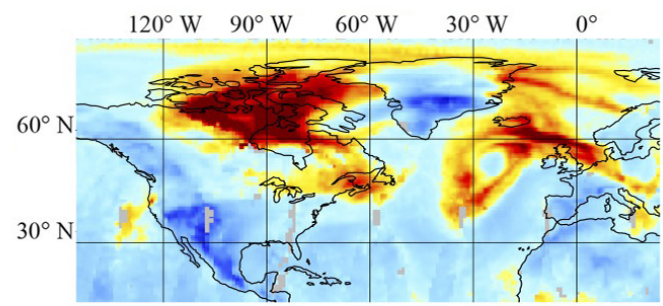

(f) 21 August 2017

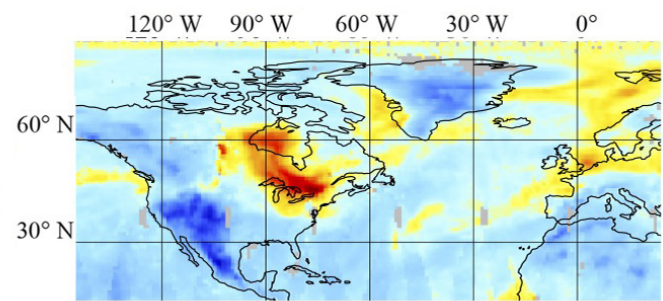

(h) 25 August 2017

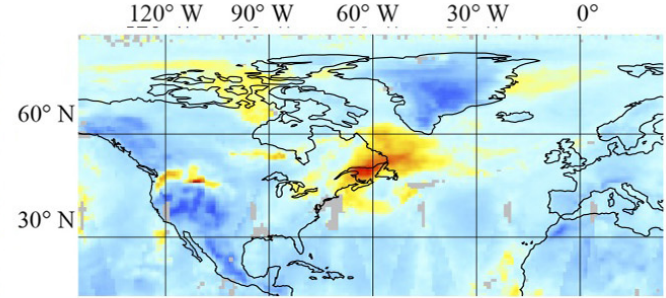

(j) 29 August 2017

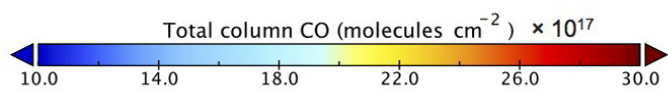

Figure 6. Total $\mathrm{CO}$ concentration (molecules $\mathrm{cm}^{-2}$ ) retrieved from AIRS. The maps are plotted every 2 days from 11 to 29 August 2017. 


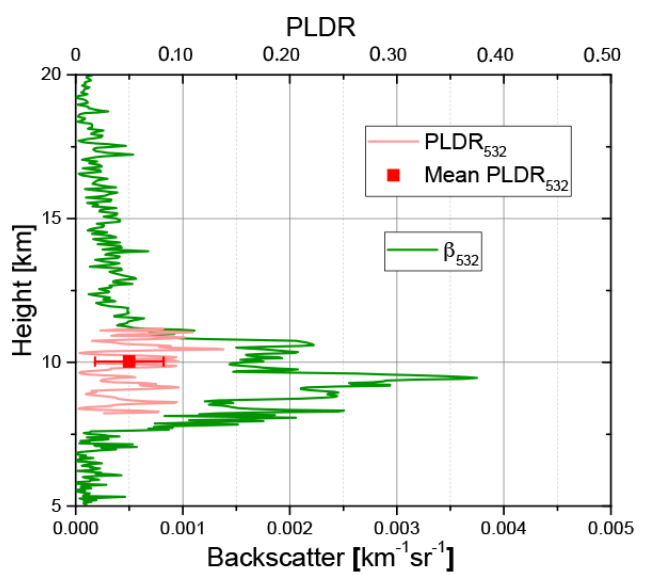

(a) $\left(61.47^{\circ} \mathrm{N}, 106.44^{\circ} \mathrm{W}\right), 14$ August

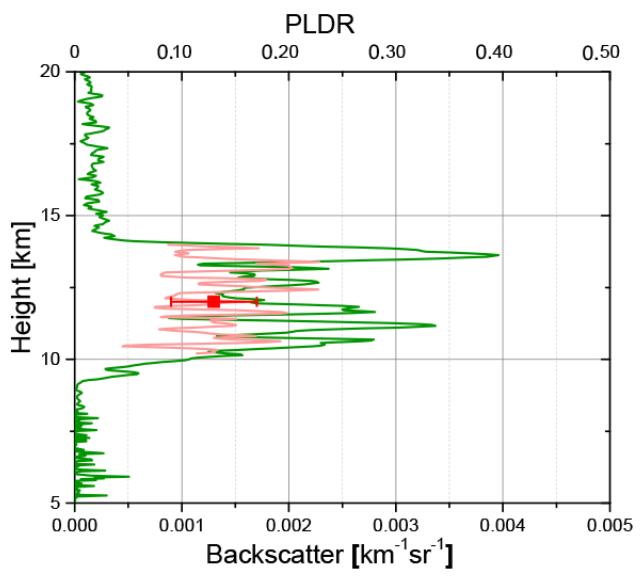

(c) $\left(46.97^{\circ} \mathrm{N}, 72.22^{\circ} \mathrm{W}\right), 17$ August

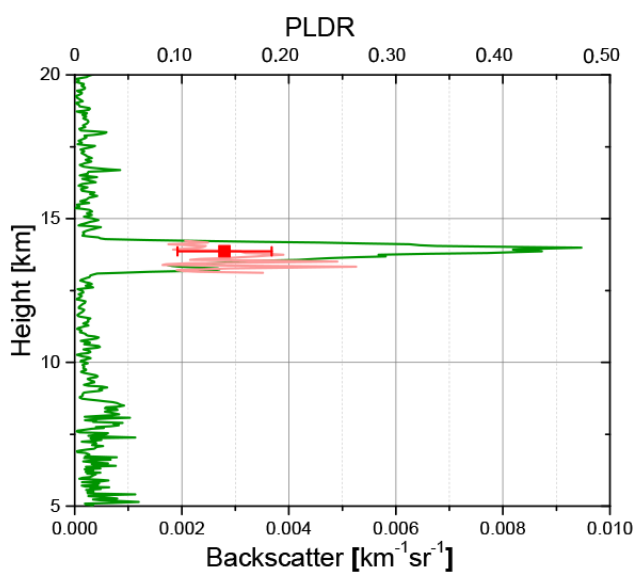

(e) $\left(55.97^{\circ} \mathrm{N}, 12.54^{\circ} \mathrm{W}\right), 21$ August

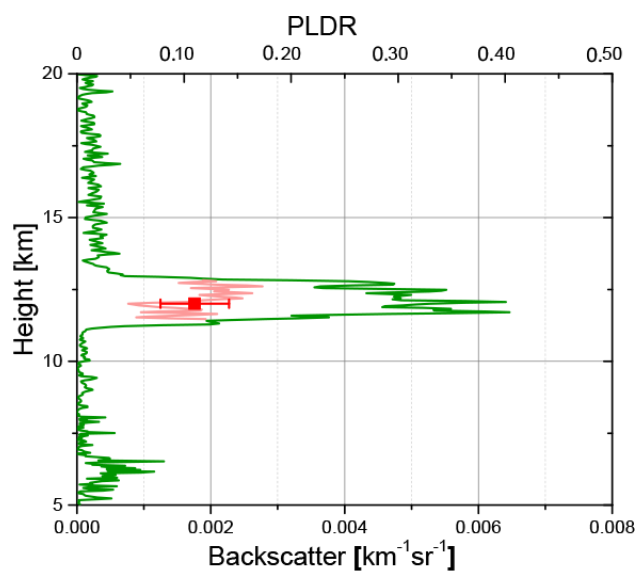

(b) $\left(62.79^{\circ} \mathrm{N}, 91.54^{\circ} \mathrm{W}\right), 15$ August

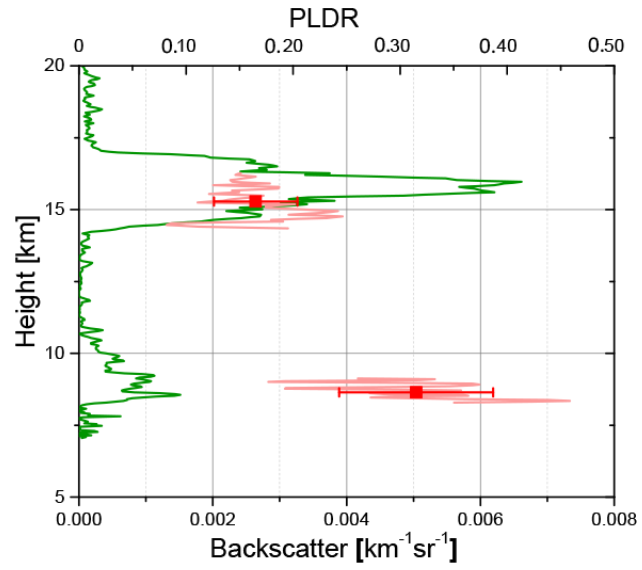

(d) $\left(42.27^{\circ} \mathrm{N}, 42.08^{\circ} \mathrm{W}\right), 19$ August

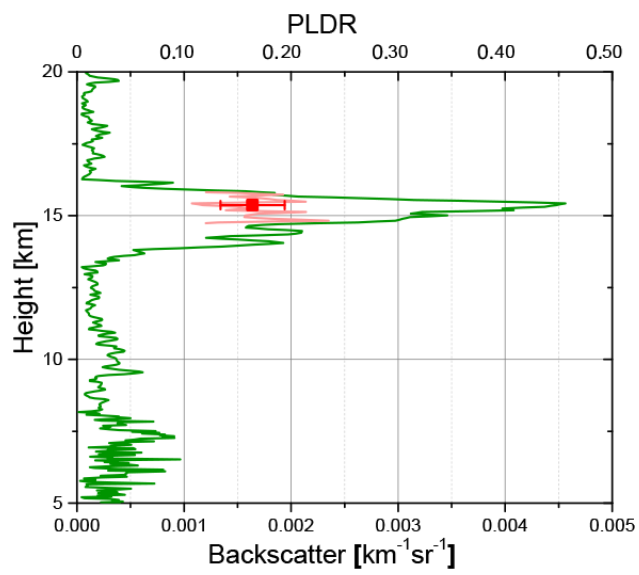

(f) $\left(52.37^{\circ} \mathrm{N}, 13.47^{\circ} \mathrm{E}\right), 23$ August

Figure 7. The profiles of backscatter coefficient and particle linear depolarization ratio (PLDR) at 532 nm from CALIPSO. Panels (a)(f) correspond to the six locations (a)-(f) in Fig. 4. The corresponding CALIPSO tracks are (a) 09:50:19, 14 August 2017; (b) 08:54:37, 15 August 2017; (c) 07:03:13, 17 August 2017; (d) 06:50:44, 19 August 2017; (e) 03:20:25, 21 August 2017; and (f) 01:29:01, 23 August 2017. A total of 20 profiles are averaged over these six locations. The solid green and pink lines represent backscatter coefficient and particle linear depolarization ratio, respectively. The red squares with error bars represent the mean particle linear depolarization ratio and the standard deviation within each layer. 


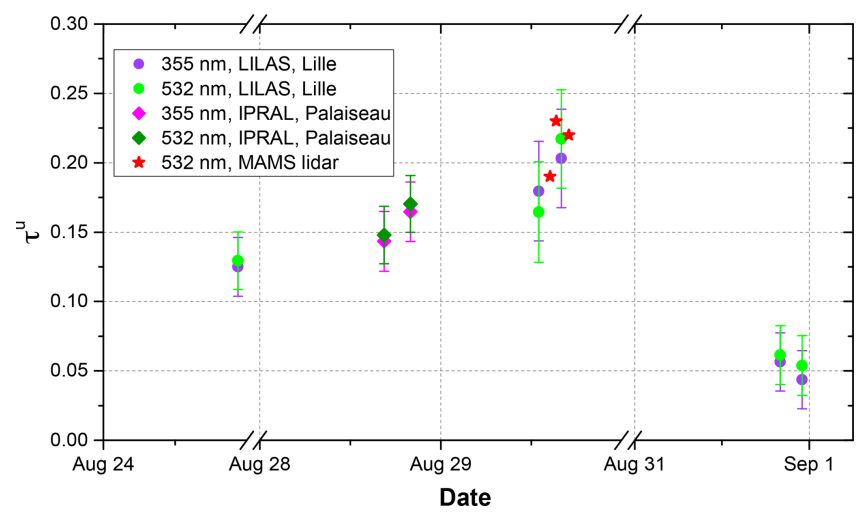

Figure 8. Optical depth of the stratospheric smoke layer at 355 and $532 \mathrm{~nm}$ estimated from lidar signals in August 2017. The optical depth estimated from LILAS (in Lille) is plotted with solid green $(532 \mathrm{~nm})$ and violet circles $(355 \mathrm{~nm})$. Optical depth calculated from IPRAL (in Palaiseau) is plotted with solid dark green $(532 \mathrm{~nm})$ and magenta $(355 \mathrm{~nm})$ diamonds. The red stars represent the optical depth calculated from the MAMS lidar.

tinction profile. As a result, the error of the estimated smoke optical depth from MAMS measurements is difficult to quantify. Here we present the optical depth from MAMS lidar for a comparison.

Table 2 summarizes the lidar ratio and particle depolarization ratio in the stratospheric aerosol layer. Lidar ratios vary between $54 \pm 9$ and $58 \pm 23 \mathrm{sr}$ at $532 \mathrm{~nm}$ and between $31 \pm 15$ and $45 \pm 9 \mathrm{sr}$ at $355 \mathrm{~nm}$. The results from two different lidar systems and with different observation times agree well, indicating that the properties of the stratospheric layer are spatially and temporally stable. We derived a higher lidar ratio at 532 than at $355 \mathrm{~nm}$, which is a characteristic feature of aged smoke and has been observed in previous studies (Wandinger et al., 2002; Murayama et al., 2004; Müller et al., 2005; Sugimoto et al., 2010). In the night of 31 August, the error of lidar ratio is about $30 \%-35 \%$, relatively higher than the other days because of the low optical depth. Although the error varies, the mean values of derived lidar ratios are relatively stable. The particle depolarization ratio decreases as wavelength increases. At $1064 \mathrm{~nm}$, the particle linear depolarization ratio is very stable, varying from $0.04 \pm 0.01$ to $0.05 \pm 0.01$. At $532 \mathrm{~nm}$, the particle linear depolarization ratio is also stable, varying from $0.18 \pm 0.03$ to $0.20 \pm 0.03$. The particle linear depolarization ratio at $355 \mathrm{~nm}$ increased from $0.23 \pm 0.03$ on 24 August to $0.28 \pm 0.08$ on 31 August. However, the increase is within the range of the uncertainties. The particle depolarization ratio at $532 \mathrm{~nm}$ is in good agreement with CALIPSO observations shown in Fig. 7c-f. The particle depolarization ratio at $355 \mathrm{~nm}$ measured by LILAS is consistent with the IPRAL system. Haarig et al. (2018) measured 0.23 at $355 \mathrm{~nm}, 0.18$ at $532 \mathrm{~nm}$, and 0.04 at $1064 \mathrm{~nm}$ in the stratospheric smoke layers on 22 August 2017, showing excellent agreements with our study.
The errors of particle depolarization ratio are calculated with the method in the Appendix. The estimated errors of the particle depolarization ratio are generally below $15 \%$, except the $355 \mathrm{~nm}$ channel in the night of 31 August when the optical depth was the lowest in all the investigated observations in this study. On 31 August, the backscatter ratio, volume depolarization ratio, and molecular depolarization ratio at $355 \mathrm{~nm}$ are approximately: $3.5(50 \%), 0.15(10 \%)$, and $0.004(200 \%)$. The values in the parentheses are the relative errors of the quantity on their left. The resulting error of particle depolarization is about $28 \%$. At $532 \mathrm{~nm}$, we derive $12 \%$ of error for the particle depolarization ratio when the backscatter ratio, volume depolarization ratio, and molecular depolarization ratio are $10(50 \%), 0.15(10 \%)$, and 0.004 $(200 \%)$. In the same way, we derive less than $11 \%$ of error for the particle depolarization ratio at $1064 \mathrm{~nm}$. The error at $355 \mathrm{~nm}$ is estimated to be higher than 532 and $1064 \mathrm{~nm}$ as the interferences of molecular scattering are stronger at this channel. When the layer is optically thicker, for example, on 24 August, the error of $355 \mathrm{~nm}$ is estimated to be less than $13 \%$. Conservatively, we use $30 \%$ for the error of the particle linear depolarization ratio at $355 \mathrm{~nm}$ on 31 August and $15 \%$ for the error of the rest.

\subsection{Case study}

\subsubsection{Optical properties}

We select the night measurements of 24 August in Lille and 28 August in Palaiseau as two examples. The two systems were operating independently, so that the results from two different systems that measured at different times can be regarded as verifications for each other.

\section{August 2017, Lille}

Figure 9 shows the retrieved optical properties of the stratospheric smoke layer observed by the LILAS system in the night of 24 August in Lille. The stratospheric aerosol layer is between 17 and $18 \mathrm{~km}$, and we retrieved the extinction and backscatter profiles by assuming that the lidar ratios are $36 \mathrm{sr}$ at $355 \mathrm{~nm}$ and $54 \mathrm{sr}$ at $532 \mathrm{~nm}$. The lidar ratio at $1064 \mathrm{~nm}$ is assumed to be $60 \mathrm{sr}$. The extinction coefficient within the layer is about $0.12-0.22 \mathrm{~km}^{-1}$ at 355 and $532 \mathrm{~nm}$. It should be noted that the profile of the extinction coefficient is similar to the backscatter coefficient profile because we assume the aerosol lidar ratio is vertically constant within the smoke layer. A comparison of backscatter coefficient profile has been made (not shown) between Klett and Raman methods. We found that the difference of the backscatter coefficient profiles from the two methods is very minor, indicating that our results are reliable. Assuming a vertically constant aerosol lidar ratio in the smoke layer is not unrealistic, as one can see that the particle linear depolarization ratios in the smoke layer have no noticeable vertical varia- 
Table 2. Retrieved lidar ratios (LRs), particle linear depolarization ratios (PLDRs), layer thickness, and mean extinction coefficients from multi-wavelength lidar systems LILAS in Lille and IPRAL in Palaiseau. $\bar{\alpha}$ is the mean extinction coefficient in the stratospheric smoke layer. $\Delta L$ is the thickness of the stratospheric smoke layer. The values after " \pm " represent the errors. Error estimation is presented in the Appendix.

\begin{tabular}{l|r|rr|rr|r}
\hline Lidar system & \multicolumn{7}{|c}{ LILAS, Lille } & IPRAL, Palaiseau \\
\hline Date & 24 August & 29 August & 31 August & 28 August \\
\hline Time (UTC) & $22: 00-00: 30$ & $13: 00-16: 00$ & $16: 00-18: 00$ & $20: 00-23: 00$ & $23: 00-02: 00$ & $19: 20-21: 20$ \\
\hline$\Delta L(\mathrm{~km})$ & 1.0 & 3.0 & 3.4 & 1.4 & 1.3 & 2.3 \\
\hline $\bar{\alpha}_{355}\left(\mathrm{~km}^{-1}\right)$ & 0.12 & 0.06 & 0.06 & 0.04 & 0.03 & 0.08 \\
$\bar{\alpha}_{532}\left(\mathrm{~km}^{-1}\right)$ & 0.14 & 0.06 & 0.06 & 0.04 & 0.03 & 0.08 \\
\hline LR $_{355}(\mathrm{sr})$ & $35 \pm 6$ & $45 \pm 9$ & $41 \pm 7$ & $34 \pm 12$ & $31 \pm 15$ & $36 \pm 6$ \\
LR $_{532}(\mathrm{sr})$ & $54 \pm 9$ & $56 \pm 12$ & $54 \pm 9$ & $58 \pm 20$ & $58 \pm 23$ & $58 \pm 7$ \\
\hline PLDR $_{355}$ & $0.23 \pm 0.03$ & $0.24 \pm 0.04$ & $0.24 \pm 0.04$ & $0.28 \pm 0.08$ & $0.28 \pm 0.08$ & $0.27 \pm 0.05$ \\
PLDR $_{532}$ & $0.20 \pm 0.03$ & $0.18 \pm 0.03$ & $0.19 \pm 0.03$ & $0.18 \pm 0.03$ & $0.18 \pm 0.03$ & - \\
PLDR $_{1064}$ & $0.05 \pm 0.01$ & $0.04 \pm 0.01$ & $0.05 \pm 0.01$ & $0.05 \pm 0.01$ & $0.05 \pm 0.01$ & - \\
\hline
\end{tabular}

(a)

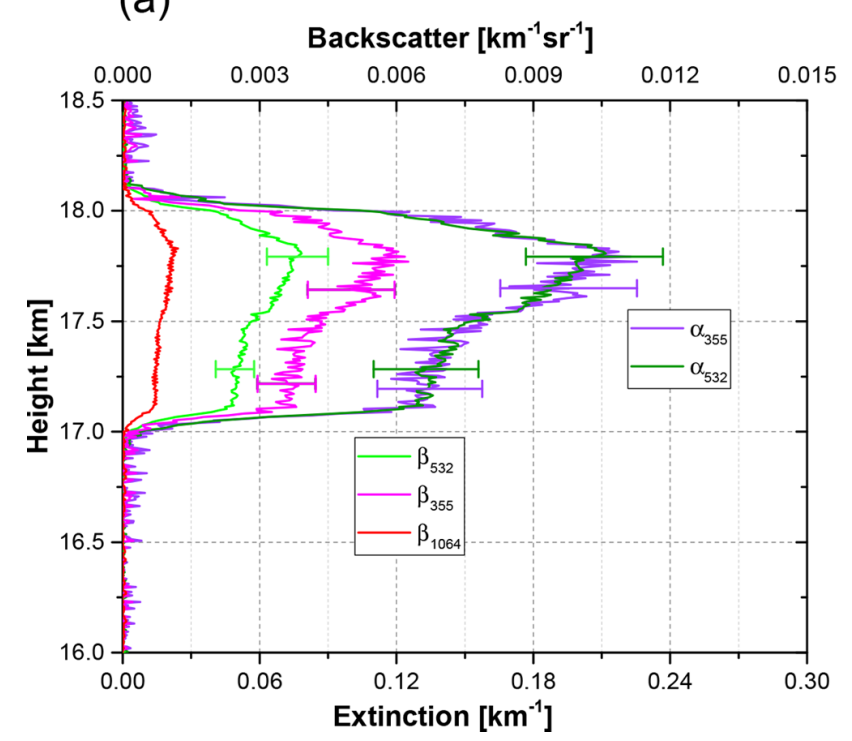

(b)

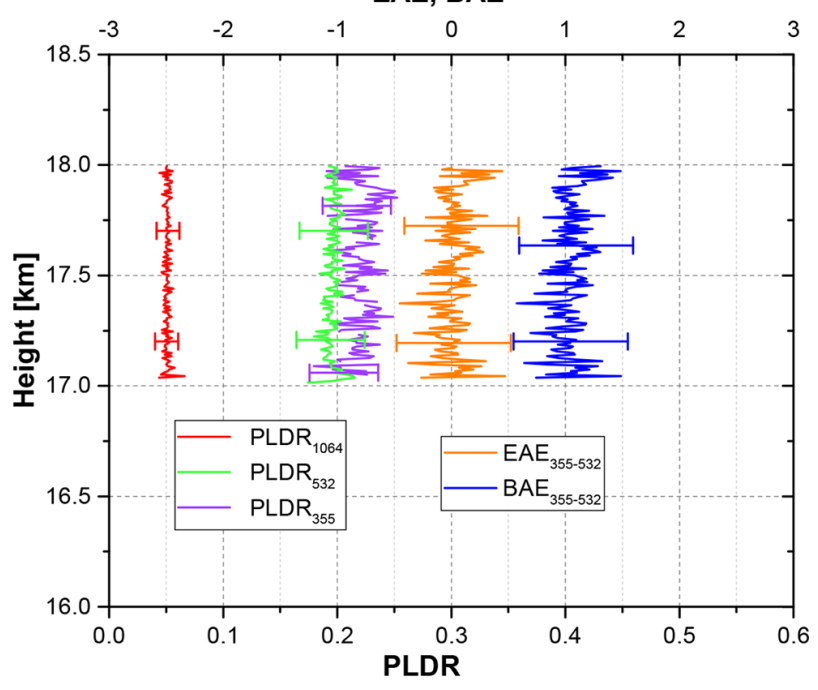

Figure 9. (a) Extinction and backscatter coefficients, (b) particle linear depolarization ratio (PLDR), and the extinction-related Ångström exponent (EAE) and backscatter-related Ångström exponent (BAE) retrieved from LILAS observations between 22:00 UTC on 24 August 2017 and 00:30 UTC on 25 August 2017 at Lille. The errors of extinction, backscatter coefficient, and corresponding Ångström exponent at 355 and $532 \mathrm{~nm}$ are attributed to the error of the optical depth.

tion, indicating that the smoke particles are well mixed. The extinction-related Ångström exponent for 355 and $532 \mathrm{~nm}$ is around $0.0 \pm 0.5$; the backscatter-related Ångström exponent at corresponding wavelengths is about $1.0 \pm 0.5$. The particle depolarization ratios decrease as wavelength increases: $0.23 \pm 0.03$ at $355 \mathrm{~nm}, 0.20 \pm 0.03$ at $532 \mathrm{~nm}$, and $0.05 \pm 0.01$ at $1064 \mathrm{~nm}$. No parameters in Fig. 9b exhibit noticeable vertical variations.

\section{August 2017, Palaiseau}

Figure 10 shows the retrieved optical parameters from IPRAL observations at 19:20-21:20 UTC on 28 August 2017 in Palaiseau. The thickness of the stratospheric layer is about $2.3 \mathrm{~km}$, spreading from 17.2 to $19.5 \mathrm{~km}$. Klett inversion was applied with an estimated lidar ratio of $36 \mathrm{sr}$ at $355 \mathrm{~nm}$ and $58 \mathrm{sr}$ at $532 \mathrm{~nm}$. At $1064 \mathrm{~nm}$ the lidar ratio was assumed to be $60 \mathrm{sr}$. The maximum extinction coefficient in the layer reached $0.12 \mathrm{~km}^{-1}$ at $532 \mathrm{~nm}$. The extinctionrelated Ångström exponent between 355 and $532 \mathrm{~nm}$ is about 
$-0.06 \pm 0.5$. The corresponding backscatter Ångström exponent is about $1.2 \pm 0.5$. The particle linear depolarization ratio at $355 \mathrm{~nm}$ is about $0.27 \pm 0.05$. The particle linear depolarization ratio at $355 \mathrm{~nm}$ and extinction and backscatter-related Ångström exponents between 355 and $532 \mathrm{~nm}$ do not show evident vertical variations.

\subsubsection{Microphysical properties}

A regularization algorithm is applied to the vertically averaged extinction coefficients (at 355 and $532 \mathrm{~nm}$ ) and backscatter coefficients (at 355, 532, and $1064 \mathrm{~nm}$ ) in Figs. 9 and 10. Treating nonspherical particles is a challenging task. Many studies have been performed to model the light scattering of nonspherical particles. The spheroid model was used to retrieved dust properties (Dubovik et al., 2006; Mishchenko et al., 1997; Veselovskii et al., 2010). Both sphere and spheroid models are used to retrieve particle microphysical properties in our study. The retrievals using sphere and spheroid models are rather consistent except the imaginary part of the refractive index. The spheroid model tends to underestimate the imaginary part of the complex refractive indices, if the measured particle depolarization ratios are used. This demonstrates the deficiency of the spheroid mode in retrieving highly-absorbent and irregular-shaped smoke particles. The size of smoke particles is expected to be not very big so that a sphere model should be able to provide reasonable results. The particle linear depolarization ratio is not used in the retrieval, and the spectral dependence of complex refractive indices is also ignored. The derived effective radius $\left(R_{\text {eff }}\right)$, volume concentration $\left(V_{\mathrm{c}}\right)$, and real $\left(m_{\mathrm{R}}\right)$ and imaginary $\left(m_{\mathrm{I}}\right)$ parts of the refractive indices are summarized in Table 3.

The retrieved particle size distributes in the range of 0.1 to $1.0 \mu \mathrm{m}$, with an effective radius (volume-weighted sphere radius) of $0.33 \pm 0.10$ for both Palaiseau data and Lille data. The volume concentration is $15 \pm 5 \mu \mathrm{m}^{3} \mathrm{~cm}^{-3}$ for Palaiseau data and $22 \pm 8 \mu \mathrm{m}^{-3} \mathrm{~cm}^{3}$ for Lille data. The complex refractive indices retrieved from Lille and Palaiseau data are also in good agreement, giving $1.55 \pm 0.05$ and $1.52 \pm 0.05$ for the real part and $0.028 \pm 0.014$ and $0.021 \pm 0.010$ for the imaginary part. The single-scattering albedos are estimated to be 0.82-0.89 for Lille data and 0.86-0.90 for Palaiseau data. The derived aerosol microphysical properties from Palaiseau and Lille data are consistent.

The errors of the retrieved parameters have been discussed in the relevant papers (Müller et al., 1999; Veselovskii et al., 2002; Pérez-Ramírez et al., 2013). About $30 \%$ of relative error is derived for the effective radius and volume concentration, \pm 0.05 (absolute value) is expected for the real part of refractive indices, and $50 \%$ is derived for the imaginary part of refractive radius. In our case, one significant limitation is that using a sphere model does not allow us to reproduce the particle depolarization ratios. We input the retrieved size distribution (not shown) and complex refractive indices in Table 3 into the spheroid model, and we found that the spheroid model ( $85 \%$ spheroid and $15 \%$ sphere) can reproduce the spectral depolarization ratios with satisfactory accuracy: $0.21,0.19$, and 0.07 at 355,532 , and $1064 \mathrm{~nm}$, respectively. However, the argument is not enough to justify that the aforementioned uncertainty estimation from previous researchers is also applicable to our retrievals. We provide this estimate as a reference, but at the current stage, we are not able to provide more quantitative and accurate error estimation for the retrieved microphysical properties.

\subsubsection{Direct radiative forcing effect}

The stratospheric plumes observed on 24 and 28 August in Lille and Palaiseau are optically thick, with an extinction coefficient about 10 times higher than in the volcanic ash observed by Ansmann et al. (1997) in April 1992, 10 months after the eruption of Mount Pinatubo. The radiative forcing imposed by the observed layers poses a curious question. We input the retrieved microphysical properties into GARRLiC/GRASP to estimate the DRF effect of the stratospheric plumes in Lille and Palaiseau. We assume the vertical volume concentration of aerosols follows the extinction profile in Figs. 9 and 10. The surface BRDF parameters for Lille and Palaiseau are taken from AERONET. The upward and downward flux and efficiencies as well as the net DRF ( $\Delta F$, with respect to a pure Rayleigh atmosphere) of the stratospheric aerosol layers are calculated and Table 4 shows the daily averaged net DRF $\left(\mathrm{W} \mathrm{m}^{-2}\right)$ at four levels: at the bottom of the atmosphere (BOA), below the stratospheric layer, above the stratospheric layer, and at the top of the atmosphere (TOA). For the layer observed in Lille on 24 August, the top and base of the stratosphere are selected as 18.4 and $16.7 \mathrm{~km}$ and for Palaiseau observations they are 20 and $17.0 \mathrm{~km}$.

At the TOA, the net DRF flux is estimated to be -1.2 and $-3.5 \mathrm{~W} \mathrm{~m}^{-2}$ for Lille and Palaiseau data, respectively. The corresponding forcing efficiencies are -7.9 and $-21.5 \mathrm{~W} \mathrm{~m}^{-2} \tau^{-1}$. At the BOA, the net DRF flux is estimated to be $-12.3 \mathrm{~W} \mathrm{~m}^{-2}$ for Lille data and $-14.5 \mathrm{~W} \mathrm{~m}^{-2}$ for Palaiseau data. The corresponding forcing efficiencies are -79.6 and $-89.6 \mathrm{~W} \mathrm{~m}^{-2} \tau^{-1}$. We noticed that the difference in net DRF flux between the layer top and layer base is significant. For Lille data, we obtained $9.9 \mathrm{~W} \mathrm{~m}^{-2}$ of difference between the top and the base of the stratospheric layer and for Palaiseau, we obtained $11.1 \mathrm{~W} \mathrm{~m}^{-2}$. Because of the high imaginary part of the refractive indices, the stratospheric aerosols have the capacity of absorbing the incoming radiation, thus reducing the upward radiation at the top of the stratospheric layer and the downward radiation at the base of the stratospheric aerosol layer. The heating rate of the stratospheric layer is estimated to be $3.3 \mathrm{~K} \mathrm{day}^{-1}$ for Palaiseau data and $3.7 \mathrm{~K} \mathrm{day}^{-1}$ for Lille data. This qualitatively explains the increase in temperature within the stratospheric layer, as observed by the radiosonde measurements shown in Fig. 3. Due to high uncertainty in the retrieved particle mi- 

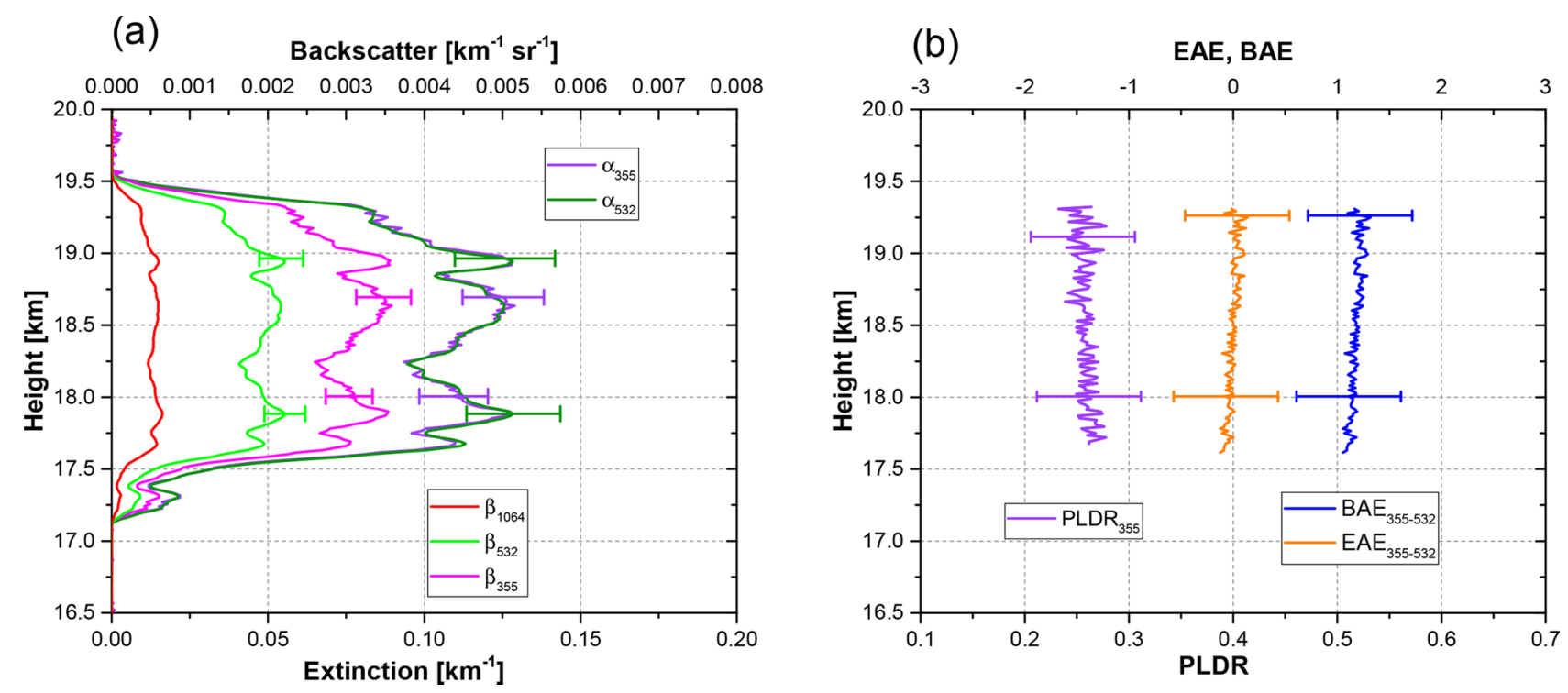

Figure 10. (a) Extinction and backscatter coefficients, (b) the particle linear depolarization ratio (PLDR) at $355 \mathrm{~nm}$, and the extinction-related Ångström exponent (EAE) and backscatter-related Ångström exponent (BAE) (between 355 and $532 \mathrm{~nm}$ ) retrieved from IPRAL observations between 19:20 and 21:20 UTC on 28 August 2017 in Palaiseau.

Table 3. Retrieved microphysical properties using the lidar data in Lille and Palaiseau. Extinction and backscatter coefficients shown in Figs. 9a and 10a are averaged in the range of 17-18.0 and 17.5-19.5 km, respectively. The averaged extinction and backscatter coefficients are used as the input of the regularization algorithm to retrieve particle microphysical properties.

\begin{tabular}{lrrrr}
\hline & $R_{\text {eff }}(\mu \mathrm{m})$ & $V_{\mathrm{c}}\left(\mu \mathrm{m}^{3} \mathrm{~cm}^{-3}\right)$ & $m_{\mathrm{R}}$ & $m_{\mathrm{I}}$ \\
\hline Lille, 24 August & $0.33 \pm 0.10$ & $22 \pm 8$ & $1.55 \pm 0.05$ & $0.028 \pm 0.014$ \\
Palaiseau, 28 August & $0.33 \pm 0.10$ & $15 \pm 5$ & $1.52 \pm 0.05$ & $0.021 \pm 0.011$ \\
\hline
\end{tabular}

Table 4. Daily averaged net DRF flux calculated by GARRLiC/GRASP. Aerosol microphysical properties in Table 3 and aerosol vertical distributions in Figs. 9a and 10a are used to calculate the DRF effect at the following four vertical levels.

\begin{tabular}{lrrrr}
\hline$\Delta F\left(\mathrm{~W} \mathrm{~m}^{-2}\right)$ & TOA & BOA & Layer top & Layer base \\
\hline Lille, 24 August & -1.2 & -12.3 & -2.1 & -12.0 \\
Palaiseau, 28 August & -3.5 & -14.5 & -2.5 & -13.6 \\
\hline
\end{tabular}

crophysical properties, the uncertainty of the calculated DRF could be large.

\section{Discussion}

The measurements revealed high particle depolarization ratios in the stratospheric smoke at 355 and $532 \mathrm{~nm}$. In particular, the particle depolarization ratio at $355 \mathrm{~nm}$ ranges from $0.23 \pm 0.03$ to $0.28 \pm 0.08$, while at $532 \mathrm{~nm}$ it is about $0.19 \pm 0.03$. The depolarization ratio at $1064 \mathrm{~nm}$ is significantly lower, about $0.05 \pm 0.01$. Similar spectral dependences of depolarization ratios, $0.20,0.09$, and 0.02 at 355, 532, and $1064 \mathrm{~nm}$, respectively, were observed by Burton et al. (2015) in a smoke plume at $7-8 \mathrm{~km}$ in altitude (on 17 July 2014) in North American wildfires. Particle depolarization ratios of 0.07 and 0.02 at 532 and $1064 \mathrm{~nm}$, respectively, were observed in a Canadian smoke plume at $6 \mathrm{~km}$ (on $2 \mathrm{Au}-$ gust 2007) over the US (Burton et al., 2012). In Burton et al. (2012) and Burton et al. (2015), the smoke traveled approximately 3 days and 6 days, respectively. The travel times in both cases are shorter than in our study. The lightscattering process leading to high particle depolarization ratios of smoke particles has not been revealed yet. In previous studies, smoke mixed with soil particles was suggested to be the explanation (Fiebig et al., 2002; Murayama et al., 2004; Müller et al., 2007a; Sugimoto et al., 2010; Burton et al., 2012, 2015; Haarig et al., 2018). Strong convections occurring in fire activities in principle are capable of lifting soil particles into the smoke plume (Sugimoto et al., 2010).

A high depolarization ratio with similar spectral dependence has been observed in fine dust particles. Miffre et al. (2016) measured the particle depolarization ratio of two Arizona Test Dust samples at backscattering angle. The radii of the dust samples are mainly below $1 \mu \mathrm{m}$. They obtained a higher depolarization ratio at $355 \mathrm{~nm}$ than at $532 \mathrm{~nm}$, and the 
depolarization ratios at both wavelengths are over 0.30 . The sharp edges and corners in the artificial dust samples are a possible reason for the measured high particle depolarization ratio. In the study of Järvinen et al. (2016), over 200 dust samples were used to measure the near-backscattering $\left(178^{\circ}\right)$ properties and it is found that, for fine-mode dust, the particle depolarization ratio has a strong size dependence. Järvinen et al. (2016) obtained about $0.12-0.20$ and $0.25-0.30$ for the depolarization ratio for equivalent particle size parameters at 355 and $532 \mathrm{~nm}$. Sakai et al. (2010) measured the depolarization of Asian and Saharan dust in the backscattering direction and obtained $0.14-0.17$ at $532 \mathrm{~nm}$ for the samples with only sub-micrometer particles and 0.39 for the samples with high concentrations of super-micrometer particles. Mamouri and Ansmann (2017) concluded that the depolarization spectrum of fine dust is $0.21 \pm 0.02$ at $355 \mathrm{~nm}, 0.16 \pm 0.02$ at $532 \mathrm{~nm}$, and $0.09 \pm 0.02$ at $1064 \mathrm{~nm}$. This spectrum is very similar to the Canadian stratospheric smoke aerosol presented in this study and Haarig et al. (2018).

However, Murayama et al. (2004) suggested that the coagulation of smoke particles to the clusters with complicated morphology is a more reasonable explanation because they found no signature of mineral dust after analyzing the chemical compositions of the smoke sample. Mishchenko et al. (2016) modeled the spectral depolarization ratios observed by Burton et al. (2015) and found that such behavior results from complicated morphology of smoke particles. Kahnert et al. (2012) modeled the optical properties of lightabsorbing carbon aggregates (LACs) embedded in a sulfate shell. It was found that the particle depolarization ratio increases with the aggregate radius (volume-equivalent sphere radius). For the case of $0.4 \mu \mathrm{m}$ aggregate radius and $20 \%$ LAC volume fraction, the computed depolarization ratios are $0.12-0.20$ at $304.0 \mathrm{~nm}, 0.08-0.18$ at $533.1 \mathrm{~nm}$, and about 0.015 at $1010.1 \mathrm{~nm}$, which are comparable with the results in this study and Haarig et al. (2018). In this study, we are not able to assess which is the dominant factor leading to the high depolarization ratios, possibly both the soil particles and smoke aging process are partially responsible.

The derived lidar ratios are from $31 \pm 15$ to $45 \pm 9 \mathrm{sr}$ for $355 \mathrm{~nm}$ and from $54 \pm 12$ to $58 \pm 23 \mathrm{sr}$ for $532 \mathrm{~nm}$. Considering the uncertainties of the lidar ratio, the derived values and the spectral dependence agree well with previous publications (Müller et al., 2005; Sugimoto et al., 2010; Haarig et al., 2018) about aged smoke observations. Haarig et al. (2018) obtained about $40 \mathrm{sr}$ at $355 \mathrm{~nm}$ and $66 \mathrm{sr}$ at $532 \mathrm{~nm}$, using the Raman method. The retrieved effective radius is about $0.33 \pm 0.10 \mu \mathrm{m}$, consistent with the particle size obtained by Haarig et al. (2018). The particle size is larger than the values of fresh smoke observed near the fire source (O'Neill et al., 2002; Nicolae et al., 2013). In particular, the retrieved particle size agrees well with the observed smoke transported from Canada to Europe (Wandinger et al., 2002; Müller et al., 2005). Müller et al. (2007b) found that the effective radius increased from $0.15-0.25 \mu \mathrm{m}$ (2-4 days after the emission) to $0.3-0.4 \mu \mathrm{m}$ after $10-20$ days of transport time, which is consistent with our results. But it is worth noting that Müller et al. (2007b) investigated only tropospheric smoke and it is not clear if this effect of the aging process is applicable to stratospheric smoke.

The real part of the refractive indices obtained in this study is $1.52 \pm 0.05$ for Palaiseau data and $1.55 \pm 0.05$ for Lille data, without considering the spectral dependence. The values are consistent with the results for tropospheric smoke (Dubovik et al., 2002; Wandinger et al., 2002; Taubman et al., 2004; Müller et al., 2005). As for the imaginary part, we derived $0.021 \pm 0.010$ from Palaiseau data and $0.028 \pm$ 0.014 from Lille data. The imaginary part of refractive indices of smoke in previous studies is diverse. Müller et al. (2005) reported the imaginary part varying around 0.003 for non-absorbing tropospheric smoke originating from aged Siberian and Canadian forest fires. Wandinger et al. (2002) obtained 0.05-0.07 for the imaginary part of Canadian smoke in the troposphere over Europe. Dubovik et al. (2002) derived about 0.01 to 0.03 for the imaginary part of biomass burning using photometer observations. The retrieved imaginary part in our study falls into the range of previously reported values. Using a sphere model in the inversion is potentially an important error source, as spheres cannot fully represent the scattering of irregular aged smoke particles. The application on dust particles (Veselovskii et al., 2010) demonstrated that retrieved volume concentration and effective radius are still reliable and the main error is attributed to the imaginary part of the refractive index. Errors in the optical data are also a potential error source of the retrieved microphysical parameters.

The relative humidity in the smoke layer is one factor that impacts the refractive indices, the particle depolarization ratio, and lidar ratio of smoke particles. However, in some studies, the relative humidity is not mentioned, thus making the comparison difficult. Special attention should be paid to the relative humidity when comparing the complex refractive indices. Mixing with other aerosol types during transport is also a potential cause of the modification of aerosol properties, and its impact is not limited to the refractive indices. In this study, the smoke layers we observed were lofted to the lower stratosphere in the source region and then transported to the observation sites. They were isolated from other tropospheric aerosol sources and not likely to mix with them during the transport. The relative humidity in the stratospheric layer was below $10 \%$, according to the radiosonde measurements. Our study provides a reference for aged smoke aerosols in a dry condition.

The retrieved particle parameters allow an estimation of direct aerosol radiative forcing. We derived $-79.6 \mathrm{~W} \mathrm{~m}^{-2} \tau^{-1}$ for the DRF efficiency at the BOA for Lille data. And for Palaiseau data, we derived $-89.6 \mathrm{~W} \mathrm{~m}^{-2} \tau^{-1}$. This indicates that the observed stratospheric aerosol layers strongly reduce the radiation reaching the terrestrial surface mainly by absorbing solar radiation. 
Derimian et al. (2016) evaluated the radiative effect of several aerosol models, among which the daily net DRF efficiency of biomass burning aerosols is estimated to be -74 to $-54 \mathrm{~W} \mathrm{~m}^{-2} \tau^{-1}$ at the BOA. Mallet et al. (2008) studied the radiative forcing of smoke and dust mixtures over Djougou and derived -68 to $-50 \mathrm{~W} \mathrm{~m}^{-2} \tau^{-1}$ for the DRF efficiency at the BOA. Our results are comparable with the values in the publications. Additionally, the mean heating rate of the stratospheric smoke layer is estimated to be about $3.5 \mathrm{~K} \mathrm{day}^{-1}$ for Lille and for Palaiseau data, which qualitatively supports the temperature increase within the stratospheric smoke layer. The warming effect in the layer is potentially responsible for the upward movements of sootcontaining aerosol plumes (Laat et al., 2012; Ansmann et al., 2018). The high uncertainty in the retrieved microphysical properties, especially the imaginary part of the refractive indices, will propagate into the DRF estimation. At the current stage, we are not able to accurately estimate the uncertainty in the microphysical properties and in the DRF calculation. Varying the imaginary part by $\pm 50 \%$, we calculated the variability in the DRF efficiency at the BOA and the heating rate, and we derived about $20 \%$ variation in the DRF efficiency at the $\mathrm{BOA}$ and $40 \%$ variation in the heating rate.

\section{Conclusion}

In the summer of 2017, large-scale wildfires spread in the west and north of Canada. The severe fire activities generated strong convections that lofted smoke plumes up to the high altitudes. After long-range transport, the smoke plumes spread over large areas. Three lidar systems in northern France observed aged smoke plumes in the stratosphere, about 10-17 days after the intense fire emissions in midAugust. Unlike fresh smoke particles, the aged smoke particles showed surprisingly high particle depolarization ratios, indicating the presence of irregular smoke particles. Lidar data inversion revealed that the smoke particles are relatively bigger compared to fresh smoke particles and very absorbent. The strong absorption of the observed smoke plumes is related to the perturbation of the temperature profile and the ascent of the plume when exposed to sunlight. In addition, the DRF estimation indicated that the stratospheric smoke can strongly reduce the radiation reaching the bottom of the atmosphere.

This study shows the capability of multi-wavelength Raman lidar in aerosol profiling and characterization. We reported important optical and microphysical properties derived from lidar observations; these results help to improve our knowledge about smoke particles and aerosol classification, which is an important topic in the lidar community. Future improvements in better quantifying the uncertainty in the optical and microphysical properties are highly anticipated. Moreover, this event is also a good opportunity for the study of the atmospheric model. The injection of smoke into the upper troposphere and lower stratosphere by strong convection needs to be considered in atmospheric models. The self-lifting of absorbing smoke is not yet considered in any aerosol transport model. Additionally, this event provides a favorable chance for studying smoke aging processes, the smoke plumes stayed in the stratosphere more than 1 month and were observed by ground-based lidars and CALIPSO. Much more effort is needed in investigating these measurements.

Data availability. The satellite data from OMPS and AIRS can be found in NASA's GES DIS service center. CALIPSO data are obtained from the Langley Atmospheric Science Data Center. The radiosonde data are taken from the website of the University of Wyoming (http://weather.uwyo.edu/upperair/sounding.html, last access: 15 January 2019). All the lidar data used in this paper and data processing code or softwares are available upon request to the corresponding author. 


\section{Appendix A: Error estimation}

\section{A1 Errors of optical depth}

The errors in the lidar signal at the top and the base of the stratospheric layers are considered to be the major error sources in the error estimation of the optical depth. We estimate the error of the lidar signal $\bar{P}\left(\lambda, r_{\text {top }}\right)$ and $\bar{P}\left(\lambda, r_{\text {base }}\right)$ to be $3 \%-5 \%$, based on the statistical error of photon distributions. According to Eq. (2), the error of the optical depth, $\frac{\Delta \tau^{u}}{\tau^{u}}$, is written as

$$
\begin{aligned}
\left(\frac{\Delta \tau^{u}}{\tau^{u}}\right)^{2} & =F_{\bar{P}_{\text {top }}}\left(\frac{\Delta \bar{P}\left(\lambda, r_{\text {top }}\right)}{\bar{P}\left(\lambda, r_{\text {top }}\right)}\right)^{2} \\
& +F_{\bar{P}_{\text {base }}}\left(\frac{\Delta \bar{P}\left(\lambda, r_{\text {base }}\right)}{\bar{P}\left(\lambda, r_{\text {base }}\right)}\right)^{2}, \\
F_{\bar{P}_{\text {top base }}} & =\left(\frac{\bar{P}\left(\lambda, r_{\text {top base }}\right)}{\tau^{u}} \frac{\partial \tau^{u}}{\partial \bar{P}\left(\lambda, r_{\text {top }, \text { base }}\right)}\right)^{2},
\end{aligned}
$$

where $\Delta \tau^{u}$ represents the absolute error of $\tau^{u}$. The calculation of molecular extinction and backscattering coefficient is based on the study of Bucholtz (1995). The temperature and pressure profiles are taken from the closest radiosonde stations, Trappes and Beauvechain, and the errors of molecular scattering are neglected.

The error of optical depth propagates into the lidar ratio and vertically integrated backscatter coefficient. Additionally, the error of the lidar ratio also relies on the step width of lidar ratio between two consecutive iterations and the fitting error of the optical depth of the stratospheric aerosol layer, which can be limited by narrowing the step of the iteration. In our calculation, we use a step of $0.5 \mathrm{sr}$ and achieve the fitting error of optical depth of less than $1 \%$ which is negligible compared to the contribution of the error of optical depth to the error of lidar ratio. However, we can basically estimate the error of the integral of the backscatter coefficient within the stratospheric aerosol layer, not the error of the backscatter coefficient profile.

\section{A2 Errors of Ångström exponent}

Ångström exponent $\AA$ is defined as follows:

$\frac{x_{\lambda_{1}}}{x_{\lambda_{2}}}=\left(\frac{\lambda_{1}}{\lambda_{2}}\right)^{-\AA}$

where $x$ is usually the optical quantities such as optical depth $\tau$, extinction coefficient $\alpha$, and backscatter coefficient $\beta$. The error of the Angström exponent results from the error of the optical quantities at two involved wavelengths:

$$
(\Delta \AA)^{2}=\left(\log \left(\frac{\lambda_{1}}{\lambda_{2}}\right)\right)^{-2}\left[\left(\frac{\Delta x_{\lambda_{1}}}{x_{\lambda_{1}}}\right)^{2}+\left(\frac{\Delta x_{\lambda_{2}}}{x_{\lambda_{2}}}\right)^{2}\right],
$$

where $\Delta x$ is the error of the quantity $x$ in absolute values. When the error of the optical depth at 355 and $532 \mathrm{~nm}$ is approximately $15 \%$, the resulting error in the Angström exponent is about 0.5 .

\section{A3 Errors of particle depolarization ratio}

According to Eq. (3), the error of the particle depolarization ratio lies in three terms: the backscatter ratio $R$, volume depolarization ratio $\delta_{\mathrm{v}}$, and molecular depolarization ratio $\delta_{\mathrm{m}}$.

$$
\begin{aligned}
& \left(\frac{\Delta \delta_{\mathrm{p}}}{\delta_{\mathrm{p}}}\right)^{2}=F_{R}\left(\frac{\Delta R}{R}\right)^{2}+F_{\delta_{\mathrm{v}}}\left(\frac{\Delta \delta_{\mathrm{v}}}{\delta_{\mathrm{v}}}\right)^{2}+F_{\delta_{\mathrm{m}}}\left(\frac{\Delta \delta_{\mathrm{m}}}{\delta_{\mathrm{m}}}\right)^{2}, \\
& F_{X}=\left(\frac{X}{\delta_{\mathrm{p}}} \frac{\partial \delta_{\mathrm{p}}}{\partial X}\right)^{2}, X=R, \delta_{\mathrm{v}}, \delta_{\mathrm{m}} .
\end{aligned}
$$

As the backscatter ratio and the volume depolarization increase, the dependence of particle depolarization ratio on the backscatter ratio decreases. In the stratospheric smoke layer, the measured volume depolarization ratio is higher in the shorter wavelength and the backscatter ratio is higher in the longer wavelength; the increased volume depolarization ratio or the backscatter ratio allows us to conservatively assume a preliminary error level for the backscatter ratio $R$. The potential error sources of the volume depolarization come from the optics and the polarization calibration. The optics have been carefully maintained and adjusted to minimize the errors originating from misalignments. After longterm lidar operation and monitoring of the depolarization calibration, we conservatively expect $10 \%$ relative errors in the volume depolarization ratio. The theoretical molecular depolarization ratio is calculated to be 0.0036 with negligible wavelength dependence (Miles et al., 2001). In the historical record since 2013, LILAS measured molecular depolarization ratios of approximately $0.005-0.013$ at $532 \mathrm{~nm}$, $0.012-0.018$ at $355 \mathrm{~nm}$, and 0.007-0.010 at $1064 \mathrm{~nm}$. IPRAL measured a molecular depolarization ratio of about 0.020 at $355 \mathrm{~nm}$ in this study. Molecular depolarization ratios measured by both the LILAS and IPRAL systems exceed the theoretical value. In addition to the error in the polarization calibration, the error of molecular depolarization ratio arises mainly from the optics, more precisely, the cross-talks between the two polarization channels. The imperfections of the optics cannot be avoided, but a careful characterization is helpful to eliminate the cross-talks as much as possible (Freudenthaler, 2016). In our study, we simply assume $200 \%$ and $300 \%$ for the error of molecular depolarization ratio measured by the LILAS and IPRAL systems, respectively. The total error of the particle depolarization ratio is calculated according to Eq. (A5). 
Author contributions. QH carried out the experiments at the Lille station, processed the data, and wrote the paper. PG and OD supervised the project and helped with paper correction. IV helped in the data analysis and paper correction. JBA contributed in providing IPRAL measurements and paper correction. IEP performed experiments using the MAMS system, analyzed the data, and helped with paper corrections. TP contributed in LILAS measurements and calibration (with $\mathrm{QH}$ ). $\mathrm{MH}$ and $\mathrm{CP}$ helped in paper correction and IPRAL operation. AL and XH contributed in developing and implementing the GARRLiC/GRASP algorithm and radiative transfer code, respectively. CC helped in obtaining and interpreting satellite products. BT helped in paper correction.

Special issue statement. This article is part of the special issue "EARLINET aerosol profiling: contributions to atmospheric and climate research". It is not associated with a conference.

Competing interests. The authors declare that they have no conflict of interest.

Acknowledgements. We wish to thank the ESA/IDEAS program (ESRIN/VEGA 4000111304/14/I-AM), who supported this work. FEDER/Region Hauts-de-France and CaPPA Labex are acknowledged for their support for the LILAS multi-wavelength Raman lidar and MAMS systems. H2020-ACTRIS-2/LiCAL calibration center, EARLINET, ACTRIS-France, ANRT France, CIMEL Electronique, and Service National Observation PHOTONS/AERONET from CNRS-INSU are acknowledged for their support. The development of lidar retrieval algorithms was supported by the Russian Science Foundation (project 16-17-10241). The authors would like to acknowledge the use of the GRASP inversion algorithm (http://www.grasp-open.com, 16 January 2019) in this work. NASA and the Langley Atmospheric Science Data Center are acknowledged for providing satellite products. The SIRTA observatory and supporting institutes are acknowledged for providing IPRAL data. Finally we thank all the co-authors for their kind cooperation and professional help.

Edited by: Vassilis Amiridis

Reviewed by: three anonymous referees

\section{References}

Andreae, M. O., Browell, E. V., Garstang, M., Gregory, G., Harriss, R., Hill, G., Jacob, D. J., Pereira, M., Sachse, G., Setzer, A., Silva Dias, P. L., Talbot, R. W., Torres, A. L., and Wofsy, S. C.: Biomass-burning emissions and associated haze layers over Amazonia, J. Geophys. Res.-Atmos., 93, 1509-1527, 1988.

Ansmann, A., Riebesell, M., Wandinger, U., Weitkamp, C., Voss, E., Lahmann, W., and Michaelis, W.: Combined Raman elasticbackscatter lidar for vertical profiling of moisture, aerosol extinction, backscatter, and lidar ratio, Appl. Phys. B, 55, 18-28, 1992.

Ansmann, A., Mattis, I., Wandinger, U., Wagner, F., Reichardt, J., and Deshler, T.: Evolution of the Pinatubo aerosol: Raman lidar observations of particle optical depth, effective radius, mass, and surface area over Central Europe at 53.4 N, J. Atmos. Sci., 54, 2630-2641, 1997.

Ansmann, A., Baars, H., Chudnovsky, A., Mattis, I., Veselovskii, I., Haarig, M., Seifert, P., Engelmann, R., and Wandinger, U.: Extreme levels of Canadian wildfire smoke in the stratosphere over central Europe on 21-22 August 2017, Atmos. Chem. Phys., 18, 11831-11845, https://doi.org/10.5194/acp-18-118312018, 2018.

Böckmann, C., Wandinger, U., Ansmann, A., Bösenberg, J., Amiridis, V., Boselli, A., Delaval, A., De Tomasi, F., Frioud, M., Grigorov, I. V., Hågård, A., Horvat, M., Iarlori, M., Komguem, L., Kreipl, S., Larchevêque, G., Matthias, V., Papayannis, A., Pappalardo, G., Rocadenbosch, F., Rodrigues, J. A., Schneider, J., Shcherbakov, V., and Wiegner, M.: Aerosol lidar intercomparison in the framework of the EARLINET project. 2. Aerosol backscatter algorithms, Appl. Optics, 43, 977-989, 2004.

Bösenberg, J., Matthias, V., Linné, H., Comerón Tejero, A., Rocadenbosch Burillo, F., Pérez López, C., and Baldasano Recio, J. M.: EARLINET: A European Aerosol Research Lidar Network to establish an aerosol climatology, Report, Max-Planck-Institut für Meteorologie, 1-191, 2003.

Bovchaliuk, V., Goloub, P., Podvin, T., Veselovskii, I., Tanre, D., Chaikovsky, A., Dubovik, O., Mortier, A., Lopatin, A., Korenskiy, M., and Victori, S.: Comparison of aerosol properties retrieved using GARRLiC, LIRIC, and Raman algorithms applied to multi-wavelength lidar and sun/sky-photometer data, Atmos. Meas. Tech., 9, 3391-3405, https://doi.org/10.5194/amt-9-33912016, 2016.

Bravo-Aranda, J. A., Belegante, L., Freudenthaler, V., AladosArboledas, L., Nicolae, D., Granados-Muñoz, M. J., GuerreroRascado, J. L., Amodeo, A., D’Amico, G., Engelmann, R., Pappalardo, G., Kokkalis, P., Mamouri, R., Papayannis, A., NavasGuzmán, F., Olmo, F. J., Wandinger, U., Amato, F., and Haeffelin, M.: Assessment of lidar depolarization uncertainty by means of a polarimetric lidar simulator, Atmos. Meas. Tech., 9, 49354953, https://doi.org/10.5194/amt-9-4935-2016, 2016.

Bucholtz, A.: Rayleigh-scattering calculations for the terrestrial atmosphere, Appl. Optics, 34, 2765-2773, 1995.

Burton, S. P., Ferrare, R. A., Hostetler, C. A., Hair, J. W., Rogers, R. R., Obland, M. D., Butler, C. F., Cook, A. L., Harper, D. B., and Froyd, K. D.: Aerosol classification using airborne High Spectral Resolution Lidar measurements - methodology and examples, Atmos. Meas. Tech., 5, 73-98, https://doi.org/10.5194/amt-5-732012, 2012.

Burton, S. P., Hair, J. W., Kahnert, M., Ferrare, R. A., Hostetler, C. A., Cook, A. L., Harper, D. B., Berkoff, T. A., Seaman, S. T., Collins, J. E., Fenn, M. A., and Rogers, R. R.: Observations of the spectral dependence of linear particle depolarization ratio of aerosols using NASA Langley airborne High Spectral Resolution Lidar, Atmos. Chem. Phys., 15, 13453-13473, https://doi.org/10.5194/acp-15-13453-2015, 2015.

Derimian, Y., Dubovik, O., Huang, X., Lapyonok, T., Litvinov, P., Kostinski, A. B., Dubuisson, P., and Ducos, F.: Comprehensive tool for calculation of radiative fluxes: illustration of shortwave aerosol radiative effect sensitivities to the details in aerosol and underlying surface characteristics, Atmos. Chem. Phys., 16, 5763-5780, https://doi.org/10.5194/acp-16-5763-2016, 2016. 
Deshler, T.: A review of global stratospheric aerosol: Measurements, importance, life cycle, and local stratospheric aerosol, Atmos. Res., 90, 223-232, 2008.

Dubovik, O., Holben, B., Eck, T. F., Smirnov, A., Kaufman, Y. J., King, M. D., Tanré, D., and Slutsker, I.: Variability of absorption and optical properties of key aerosol types observed in worldwide locations, J. Atmos. Sci., 59, 590-608, 2002.

Dubovik, O., Sinyuk, A., Lapyonok, T., Holben, B. N., Mishchenko, M., Yang, P., Eck, T. F., Volten, H., Munoz, O., Veihelmann, B., Veihelmann, B., van der Zande, W. J., Leon, J.-F., Sorokin, M., and Slutsker, I.: Application of spheroid models to account for aerosol particle nonsphericity in remote sensing of desert dust, J. Geophys. Res.-Atmos., 111, D11208, https://doi.org/10.1029/2005JD006619, 2006.

Dubovik, O., Lapyonok, T., Litvinov, P., Herman, M., Fuertes, D., Ducos, F., Lopatin, A., Chaikovsky, A., Torres, B., Derimian, Y., Huang, X., Aspetsberger, M., and Federspiel, C.: GRASP: a versatile algorithm for characterizing the atmosphere, SPIE Newsroom, 25, https://doi.org/10.1117/2.1201408.005558, 2014.

Fiebig, M., Petzold, A., Wandinger, U., Wendisch, M., Kiemle, C., Stifter, A., Ebert, M., Rother, T., and Leiterer, U.: Optical closure for an aerosol column: Method, accuracy, and inferable properties applied to a biomass-burning aerosol and its radiative forcing, J. Geophys. Res.-Atmos., 107, LAC 12-1-LAC 12-15, https://doi.org/10.1029/2000JD000192, 2002.

Freudenthaler, V.: About the effects of polarising optics on lidar signals and the $\Delta 90$ calibration, Atmos. Meas. Tech., 9, 41814255, https://doi.org/10.5194/amt-9-4181-2016, 2016.

Freudenthaler, V., Esselborn, M., Wiegner, M., Heese, B., Tesche, M., Ansmann, A., Müller, D., Althausen, D., Wirth, M., Fix, A., Ehret, G., Knippertz, P., Toledano, C., Gasteiger, J., Garhammer, M., and Seefeldner, M.: Depolarization ratio profiling at several wavelengths in pure Saharan dust during SAMUM 2006, Tellus B, 61, 165-179, 2009.

Freudenthaler, V., Linné, H., Chaikovski, A., Rabus, D., and Groß, S.: EARLINET lidar quality assurance tools, Atmos. Meas. Tech. Discuss., https://doi.org/10.5194/amt-2017-395, in review, 2018.

Fromm, M., Alfred, J., Hoppel, K., Hornstein, J., Bevilacqua, R., Shettle, E., Servranckx, R., Li, Z., and Stocks, B.: Observations of boreal forest fire smoke in the stratosphere by POAM III, SAGE II, and lidar in 1998, Geophys. Res. Lett., 27, 1407-1410, 2000.

Fromm, M., Bevilacqua, R., Servranckx, R., Rosen, J., Thayer, J. P., Herman, J., and Larko, D.: Pyro-cumulonimbus injection of smoke to the stratosphere: Observations and impact of a super blowup in northwestern Canada on 34 August 1998, J. Geophys. Res.-Atmos., 110, D08205, https://doi.org/10.1029/2004JD005350, 2005.

Fromm, M., Shettle, E., Fricke, K., Ritter, C., Trickl, T., Giehl, H., Gerding, M., Barnes, J., O’Neill, M., Massie, S., Blum, U., McDermid, I. S., Leblanc, T., and Deshler, T.: Stratospheric impact of the Chisholm pyrocumulonimbus eruption: 2. Vertical profile perspective, J. Geophys. Res.-Atmos., 113, D08203, https://doi.org/10.1029/2007jd009147, 2008.

Fromm, M. D. and Servranckx, R.: Transport of forest fire smoke above the tropopause by supercell convection, Geophys. Res. Lett., 30, https://doi.org/10.1029/2002g1016820, 2003.

Haarig, M., Ansmann, A., Baars, H., Jimenez, C., Veselovskii, I., Engelmann, R., and Althausen, D.: Depolarization and lidar ratios at 355, 532, and $1064 \mathrm{~nm}$ and microphysical properties of aged tropospheric and stratospheric Canadian wildfire smoke, Atmos. Chem. Phys., 18, 11847-11861, https://doi.org/10.5194/acp-18-11847-2018, 2018.

Haeffelin, M., Barthès, L., Bock, O., Boitel, C., Bony, S., Bouniol, D., Chepfer, H., Chiriaco, M., Cuesta, J., Delanoë, J., Drobinski, P., Dufresne, J.-L., Flamant, C., Grall, M., Hodzic, A., Hourdin, F., Lapouge, F., Lemaître, Y., Mathieu, A., Morille, Y., Naud, C., Noël, V., O’Hirok, W., Pelon, J., Pietras, C., Protat, A., Romand, B., Scialom, G., and Vautard, R.: SIRTA, a ground-based atmospheric observatory for cloud and aerosol research, Ann. Geophys., 23, 253-275, https://doi.org/10.5194/angeo-23-253-2005, 2005.

Haskins, R. and Kaplan, L.: Remote sensing of trace gases using the Atmospheric InfraRed Sounder, in: IRS, 92, 278-281, 1992.

Hofmann, D., Barnes, J., O’Neill, M., Trudeau, M., and Neely, R.: Increase in background stratospheric aerosol observed with lidar at Mauna Loa Observatory and Boulder, Colorado, Geophys. Res. Lett., 36, L15808, https://doi.org/10.1029/2009GL039008, 2009.

Hsu, N. C., Herman, J., Torres, O., Holben, B., Tanre, D., Eck, T., Smirnov, A., Chatenet, B., and Lavenu, F.: Comparisons of the TOMS aerosol index with Sun-photometer aerosol optical thickness: Results and applications, J. Geophys. Res.-Atmos., 104, 6269-6279, 1999.

Jaross, G.: OMPS-NPP L3 NM Ozone $\left(\mathrm{O}_{3}\right)$ Total Column 1.0 deg grid daily V2, Greenbelt, MD, USA, Goddard Earth Sciences Data and Information Services Center (GES DISC), https://doi.org/10.5067/7Y7KSA1QNQP8, 2017.

Järvinen, E., Kemppinen, O., Nousiainen, T., Kociok, T., Möhler, O., Leisner, T., and Schnaiter, M.: Laboratory investigations of mineral dust near-backscattering depolarization ratios, J. Quant. Spectrosc. Ra., 178, 192-208, 2016.

Kahn, B. H., Irion, F. W., Dang, V. T., Manning, E. M., Nasiri, S. L., Naud, C. M., Blaisdell, J. M., Schreier, M. M., Yue, Q., Bowman, K. W., Fetzer, E. J., Hulley, G. C., Liou, K. N., Lubin, D., Ou, S. C., Susskind, J., Takano, Y., Tian, B., and Worden, J. R.: The Atmospheric Infrared Sounder version 6 cloud products, Atmos. Chem. Phys., 14, 399-426, https://doi.org/10.5194/acp-14-3992014, 2014.

Kahnert, M., Nousiainen, T., Lindqvist, H., and Ebert, M.: Optical properties of light absorbing carbon aggregates mixed with sulfate: assessment of different model geometries for climate forcing calculations, Optics Exp., 20, 10042-10058, 2012.

Karol, Y., Tanré, D., Goloub, P., Vervaerde, C., Balois, J. Y., Blarel, L., Podvin, T., Mortier, A., and Chaikovsky, A.: Airborne sun photometer PLASMA: concept, measurements, comparison of aerosol extinction vertical profile with lidar, Atmos. Meas. Tech., 6, 2383-2389, https://doi.org/10.5194/amt-6-2383-2013, 2013.

Khaykin, S., Godin-Beekmann, S., Hauchecorne, A., Pelon, J., Ravetta, F., and Keckhut, P.: Stratospheric smoke with unprecedentedly high backscatter observed by lidars above southern France, Geophys. Res. Lett., 45, 1639-1646, 2018.

Khaykin, S. M., Godin-Beekmann, S., Keckhut, P., Hauchecorne, A., Jumelet, J., Vernier, J.-P., Bourassa, A., Degenstein, D. A., Rieger, L. A., Bingen, C., Vanhellemont, F., Robert, C., DeLand, M., and Bhartia, P. K.: Variability and evolution of the midlatitude stratospheric aerosol budget from 22 years of ground-based 
lidar and satellite observations, Atmos. Chem. Phys., 17, 18291845, https://doi.org/10.5194/acp-17-1829-2017, 2017.

Klett, J. D.: Lidar inversion with variable backscatter/extinction ratios, Appl. Optics, 24, 1638-1643, 1985.

Kremser, S., Thomason, L. W., Hobe, M., Hermann, M., Deshler, T., Timmreck, C., Toohey, M., Stenke, A., Schwarz, J. P., Weigel, R., Fueglistaler, S., Prata, F. J., Vernier, J.-P., Schlager, H., Barnes, E. J., Antuna-Marrero, J.-C., Fairlie, D., Palm, M., Mahieu, E., Notholt, J., Rex, M., Bingen, C., Vanhellemont, F., Bourassa, A., Plane, J. M. C., Klocke, D., Carn, S. A., Clarisse, L., Trickl, T., Neely, R. D., James, A., Rieger, L., Wilson, C. J., and Meland, B.: Stratospheric aerosol - Observations, processes, and impact on climate, Rev. Geophys., 54, 278-335, 2016.

Laat, A., Stein Zweers, D. C., and Boers, R.: A solar escalator: Observational evidence of the self-lifting of smoke and aerosols by absorption of solar radiation in the February 2009 Australian Black Saturday plume, J. Geophys. Res.-Atmos., 117, D04204, https://doi.org/10.1029/2011JD017016, 2012.

Lenoble, J., Herman, M., Deuzé, J., Lafrance, B., Santer, R., and Tanré, D.: A successive order of scattering code for solving the vector equation of transfer in the earth's atmosphere with aerosols, J. Quant. Spectrosc. Ra., 107, 479-507, 2007.

Lopatin, A., Dubovik, O., Chaikovsky, A., Goloub, P., Lapyonok, T., Tanré, D., and Litvinov, P.: Enhancement of aerosol characterization using synergy of lidar and sun-photometer coincident observations: the GARRLiC algorithm, Atmos. Meas. Tech., 6, 2065-2088, https://doi.org/10.5194/amt-6-2065-2013, 2013.

Luderer, G., Trentmann, J., Winterrath, T., Textor, C., Herzog, M., Graf, H. F., and Andreae, M. O.: Modeling of biomass smoke injection into the lower stratosphere by a large forest fire (Part II): sensitivity studies, Atmos. Chem. Phys., 6, 5261-5277, https://doi.org/10.5194/acp-6-5261-2006, 2006.

Mallet, M., Pont, V., Liousse, C., Gomes, L., Pelon, J., Osborne, S., Haywood, J., Roger, J.-C., Dubuisson, P., Mariscal, A., Thouret, V., and Goloub, P.: Aerosol direct radiative forcing over Djougou (northern Benin) during the African Monsoon Multidisciplinary Analysis dry season experiment (Special Observation Period-0), J. Geophys. Res.-Atmos., 113, D00C01, https://doi.org/10.1029/2007JD009419, 2008.

Mamouri, R.-E. and Ansmann, A.: Potential of polarization/Raman lidar to separate fine dust, coarse dust, maritime, and anthropogenic aerosol profiles, Atmos. Meas. Tech., 10, 3403-3427, https://doi.org/10.5194/amt-10-3403-2017, 2017.

Matthais, V., Freudenthaler, V., Amodeo, A., Balin, I., Balis, D., Bösenberg, J., Chaikovsky, A., Chourdakis, G., Comeron, A., Delaval, A., De Tomasi, F., Eixmann, R., Hågård, A., Komguem, L., Kreipl, S., Matthey, R., Rizi, V., Rodrigues, J. A., Wandinger, U., and Wang, X.: Aerosol lidar intercomparison in the framework of the EARLINET project. 1. Instruments, Appl. Optics, 43, 961-976, 2004.

McMillan, W., Barnet, C., Strow, L., Chahine, M., McCourt, M., Warner, J., Novelli, P., Korontzi, S., Maddy, E., and Datta, S.: Daily global maps of carbon monoxide from NASA's Atmospheric Infrared Sounder, Geophys. Res. Lett., 32, https://doi.org/10.1029/2004GL021821, 2005.

McPeters, R. D., Bhartia, P., Krueger, A. J., Herman, J. R., Wellemeyer, C. G., Seftor, C. J., Byerly, W., and Celarier, E. A.: Total Ozone Mapping Spectrometer (TOMS) Level-3 data products user's guide, available at: https://ntrs.nasa.gov/archive/nasa/casi. ntrs.nasa.gov/20010044085.pdf (last access: 15 January 2019), 2000.

Miffre, A., Mehri, T., Francis, M., and Rairoux, P.: UV-VIS depolarization from Arizona Test Dust particles at exact backscattering angle, J. Quant. Spectrosc. Ra., 169, 79-90, 2016.

Miles, R. B., Lempert, W. R., and Forkey, J. N.: Laser rayleigh scattering, Meas. Sci. Technol., 12, R33-R51, 2001.

Mishchenko, M. I., Travis, L. D., Kahn, R. A., and West, R. A.: Modeling phase functions for dustlike tropospheric aerosols using a shape mixture of randomly oriented polydisperse spheroids, J. Geophys. Res.-Atmos., 102, 16831-16847, 1997.

Mishchenko, M. I., Dlugach, J. M., and Liu, L.: Linear depolarization of lidar returns by aged smoke particles, Appl. Optics, 55, 9968-9973, 2016.

Müller, D., Wandinger, U., and Ansmann, A.: Microphysical particle parameters from extinction and backscatter lidar data by inversion with regularization: theory, Appl. Optics, 38, 2346-2357, 1999.

Müller, D., Mattis, I., Wandinger, U., Ansmann, A., Althausen, D., and Stohl, A.: Raman lidar observations of aged Siberian and Canadian forest fire smoke in the free troposphere over Germany in 2003: Microphysical particle characterization, J. Geophys. Res.-Atmos., 110, D17201, https://doi.org/10.1029/2004JD005756, 2005.

Müller, D., Ansmann, A., Mattis, I., Tesche, M., Wandinger, U., Althausen, D., and Pisani, G.: Aerosol-type-dependent lidar ratios observed with Raman lidar, J. Geophys. Res.-Atmos., 112, D16202, https://doi.org/10.1029/2006JD008292, 2007a.

Müller, D., Mattis, I., Ansmann, A., Wandinger, U., Ritter, C., and Kaiser, D.: Multiwavelength Raman lidar observations of particle growth during long-range transport of forest-fire smoke in the free troposphere, Geophys. Res. Lett., 34, L05803, https://doi.org/10.1029/2006GL027936, 2007b.

Murayama, T., Müller, D., Wada, K., Shimizu, A., Sekiguchi, M., and Tsukamoto, T.: Characterization of Asian dust and Siberian smoke with multi-wavelength Raman lidar over Tokyo, Japan in spring 2003, Geophys. Res. Lett., 31, L23103, https://doi.org/10.1029/2004GL021105, 2004.

Nicolae, D., Nemuc, A., Müller, D., Talianu, C., Vasilescu, J., Belegante, L., and Kolgotin, A.: Characterization of fresh and aged biomass burning events using multiwavelength Raman lidar and mass spectrometry, J. Geophys. Res.-Atmos., 118, 2956-2965, 2013.

O’Neill, N., Eck, T., Holben, B., Smirnov, A., Royer, A., and Li, Z.: Optical properties of boreal forest fire smoke derived from Sun photometry, J. Geophys. Res.-Atmos., 107, AAC 6-1-AAC 6-14, 2002.

Papayannis, A., Amiridis, V., Mona, L., Tsaknakis, G., Balis, D., Bösenberg, J., Chaikovski, A., De Tomasi, F., Grigorov, I., Mattis, I., Mitev, V and Mueller, Detlef and Nickovic, S and Perez, C and Pietruczuk, A and Pisani, G., Ravetta, F., Rizi, V., Sicard, M., Trickl, T., Wiegner, M., Gerding, M., and Mamouri, R. E.: Systematic lidar observations of Saharan dust over Europe in the frame of EARLINET (2000-2002), J. Geophys. Res.-Atmos., 113, D10204, https://doi.org/10.1029/2007JD009028, 2008.

Pappalardo, G., Amodeo, A., Apituley, A., Comeron, A., Freudenthaler, V., Linné, H., Ansmann, A., Bösenberg, J., D’Amico, G., Mattis, I., Mona, L., Wandinger, U., Amiridis, V., AladosArboledas, L., Nicolae, D., and Wiegner, M.: EARLINET: to- 
wards an advanced sustainable European aerosol lidar network, Atmos. Meas. Tech., 7, 2389-2409, https://doi.org/10.5194/amt7-2389-2014, 2014.

Pérez-Ramírez, D., Whiteman, D. N., Veselovskii, I., Kolgotin, A., Korenskiy, M., and Alados-Arboledas, L.: Effects of systematic and random errors on the retrieval of particle microphysical properties from multiwavelength lidar measurements using inversion with regularization, Atmos. Meas. Tech., 6, 3039-3054, https://doi.org/10.5194/amt-6-3039-2013, 2013.

Platt, C.: Lidar and radiometric observations of cirrus clouds, J. Atmos. Sci., 30, 1191-1204, 1973.

Popovici, I. E., Goloub, P., Podvin, T., Blarel, L., Loisil, R., Unga, F., Mortier, A., Deroo, C., Victori, S., Ducos, F., Torres, B., Delegove, C., Choël, M., Pujol-Söhne, N., and Pietras, C.: Description and applications of a mobile system performing onroad aerosol remote sensing and in situ measurements, Atmos. Meas. Tech., 11, 4671-4691, https://doi.org/10.5194/amt11-4671-2018, 2018.

Sakai, T., Nagai, T., Zaizen, Y., and Mano, Y.: Backscattering linear depolarization ratio measurements of mineral, sea-salt, and ammonium sulfate particles simulated in a laboratory chamber, Appl. Optics, 49, 4441-4449, 2010.

Sassen, K., Liou, K. N., Kinne, S., and Griffin, M.: Highly supercooled cirrus cloud water: Confirmation and climatic implications, Science, 227, 411-413, 1985.

Seftor, C., Jaross, G., Kowitt, M., Haken, M., Li, J., and Flynn, L.: Postlaunch performance of the Suomi National Polar-orbiting Partnership Ozone Mapping and Profiler Suite (OMPS) nadir sensors, J. Geophys. Res.-Atmos., 119, 4413-4428, 2014.

Shepherd, T. G.: Transport in the middle atmosphere, J. Meteorol. Soc. Jpn., 85, 165-191, 2007.

Sugimoto, N., Tatarov, B., Shimizu, A., Matsui, I., and Nishizawa, T.: Optical characteristics of forest-fire smoke observed with two-wavelength Mie-scattering lidars and a high-spectralresolution lidar over Japan, SOLA, 6, 93-96, 2010.

Susskind, J., Blaisdell, J. M., and Iredell, L.: Improved methodology for surface and atmospheric soundings, error estimates, and quality control procedures: the atmospheric infrared sounder science team version-6 retrieval algorithm, J. Appl. Remote Sens., 8, 084994, https://doi.org/10.1117/1.JRS.8.084994, 2014.

Taubman, B. F., Marufu, L. T., Vant-Hull, B. L., Piety, C. A., Doddridge, B. G., Dickerson, R. R., and Li, Z.: Smoke over haze: Aircraft observations of chemical and optical properties and the effects on heating rates and stability, J. Geophys. Res.-Atmos., 109, 084994-1-084994-33, https://doi.org/10.1117/1.JRS.8.084994, 2004.

Texeira, A. S. T.: AIRS/Aqua L3 Daily Standard Physical Retrieval (AIRS-only) 1 degree $\times 1$ degree V006, Greenbelt, MD, USA, Goddard Earth Sciences Data and Information Services Center (GES DISC), https://doi.org/10.5067/Aqua/AIRS/DATA303, 2013.
Trentmann, J., Luderer, G., Winterrath, T., Fromm, M. D., Servranckx, R., Textor, C., Herzog, M., Graf, H.-F., and Andreae, M. O.: Modeling of biomass smoke injection into the lower stratosphere by a large forest fire (Part I): reference simulation, Atmos. Chem. Phys., 6, 5247-5260, https://doi.org/10.5194/acp6-5247-2006, 2006.

Vallero, D.: Fundamentals of air pollution, Academic Press, 814 pp., available at: https://books.google.fr/books?hl= en\&lr=\&id $=\mathrm{iFcXAwAAQBAJ} \& o i=$ fnd $\& p g=P P 1 \& d q=$

Fundamentals+of+air+pollution+vallero\&ots=rfJer-585s\&sig= 6N7KMdclAy3x6qPn3YbPA-eoXtg\#v=onepage \&q= Fundamentals $\% 20$ of $\% 20$ air $\% 20$ pollution $\% 20$ vallero\&f=false (last access: 16 January 2019), 2014.

Veselovskii, I., Kolgotin, A., Griaznov, V., Müller, D., Wandinger, U., and Whiteman, D. N.: Inversion with regularization for the retrieval of tropospheric aerosol parameters from multiwavelength lidar sounding, Appl. Optics, 41, 3685-3699, 2002.

Veselovskii, I., Dubovik, O., Kolgotin, A., Lapyonok, T., Di Girolamo, P., Summa, D., Whiteman, D. N., Mishchenko, M., and Tanré, D.: Application of randomly oriented spheroids for retrieval of dust particle parameters from multiwavelength lidar measurements, J. Geophys. Res.-Atmos., 115, D21203, https://doi.org/10.1029/2010JD014139, 2010.

Veselovskii, I., Goloub, P., Podvin, T., Bovchaliuk, V., Derimian, Y., Augustin, P., Fourmentin, M., Tanre, D., Korenskiy, M., Whiteman, D. N., Diallo, A., Ndiaye, T., Kolgotin, A., and Dubovik, O.: Retrieval of optical and physical properties of African dust from multiwavelength Raman lidar measurements during the SHADOW campaign in Senegal, Atmos. Chem. Phys., 16, 70137028, https://doi.org/10.5194/acp-16-7013-2016, 2016.

Veselovskii, I., Goloub, P., Podvin, T., Tanre, D., Ansmann, A., Korenskiy, M., Borovoi, A., Hu, Q., and Whiteman, D.: Spectral dependence of backscattering coefficient of mixed phase clouds over West Africa measured with two-wavelength Raman polarization lidar: Features attributed to ice-crystals corner reflection, J. Quant. Spectrosc. Ra., 202, 74-80, 2017.

Wandinger, U., Müller, D., Böckmann, C., Althausen, D., Matthias, V., Bösenberg, J., Weiß, V., Fiebig, M., Wendisch, M., Stohl, A., et al.: Optical and microphysical characterization of biomassburning and industrial-pollution aerosols from-multiwavelength lidar and aircraft measurements, J. Geophys. Res.-Atmos., 107, LAC 7-1-LAC 7-20, https://doi.org/10.1029/2000JD000202, 2002.

Young, S. A.: Analysis of lidar backscatter profiles in optically thin clouds, Appl. Optics, 34, 7019-7031, 1995.

Zuev, V. V., Burlakov, V. D., Nevzorov, A. V., Pravdin, V. L., Savelieva, E. S., and Gerasimov, V. V.: 30-year lidar observations of the stratospheric aerosol layer state over Tomsk (Western Siberia, Russia), Atmos. Chem. Phys., 17, 3067-3081, https://doi.org/10.5194/acp-17-3067-2017, 2017. 